\title{
Review
}

\section{Recent Advances in Seawater Electrolysis}

\author{
Siqi Jiang ${ }^{1,2}$, Hongli Suo ${ }^{1,2, *}$, Teng Zhang ${ }^{3}$, Caizhi Liao ${ }^{4}$, Yunxiao Wang ${ }^{5}$, Qinglan Zhao ${ }^{6, *}$ and Weihong Lai ${ }^{5, *}$ \\ 1 Faculty of Materials and Manufacturing, Beijing University of Technology, Beijing 100124, China; \\ jiangsiqi@emails.bjut.edu.cn \\ 2 The Key Laboratory of Advanced Functional Materials, Ministry of Education, Beijing University of \\ Technology, Beijing 100022, China \\ 3 School of Electrical Engineering, Beijing Jiaotong University, Beijing 100044, China; tengzhang@bjut.edu.cn \\ 4 Creative Biosciences Co., Ltd., Guangzhou 510535, China; liaocaizhi@creativebio.cn \\ 5 Institute for Superconducting \& Electronic Materials, Innovation Campus, University of Wollongong, \\ Wollongong, NSW 2500, Australia; yunxiao@uow.edu.au \\ 6 Department of Chemical and Biological Engineering, The Hong Kong University of Science and Technology, \\ Clear Water Bay, Kowloon, Hong Kong, China \\ * Correspondence: honglisuo@bjut.edu.cn (H.S.); keqzhao@ust.hk (Q.Z.); w1478@uowmail.edu.au (W.L.)
}

check for updates

Citation: Jiang, S.; Suo, H.; Zhang, T.; Liao, C.; Wang, Y.; Zhao, Q.; Lai, W. Recent Advances in Seawater Electrolysis. Catalysts 2022, 12, 123. https://doi.org/10.3390/ catal12020123

Academic Editor: Nicolas Alonso-Vante

Received: 1 December 2021

Accepted: 15 January 2022

Published: 20 January 2022

Publisher's Note: MDPI stays neutral with regard to jurisdictional claims in published maps and institutional affiliations.

Copyright: (c) 2022 by the authors. Licensee MDPI, Basel, Switzerland. This article is an open access article distributed under the terms and conditions of the Creative Commons Attribution (CC BY) license (https:// creativecommons.org/licenses/by/ $4.0 /)$.

\begin{abstract}
Hydrogen energy, as a clean and renewable energy, has attracted much attention in recent years. Water electrolysis via the hydrogen evolution reaction at the cathode coupled with the oxygen evolution reaction at the anode is a promising method to produce hydrogen. Given the shortage of freshwater resources on the planet, the direct use of seawater as an electrolyte for hydrogen production has become a hot research topic. Direct use of seawater as the electrolyte for water electrolysis can reduce the cost of hydrogen production due to the great abundance and wide availability. In recent years, various high-efficiency electrocatalysts have made great progress in seawater splitting and have shown great potential. This review introduces the mechanisms and challenges of seawater splitting and summarizes the recent progress of various electrocatalysts used for hydrogen and oxygen evolution reaction in seawater electrolysis in recent years. Finally, the challenges and future opportunities of seawater electrolysis for hydrogen and oxygen production are presented.
\end{abstract}

Keywords: seawater splitting; metal oxides; metal phosphides; metal nitrides; electrocatalysts

\section{Introduction}

Due to the ever-increasing energy demand and the exponential growth of energy consumption, we are facing a great challenge caused by the shortage of fossil energy storage together with the related pollution. The energy conversion system, to generate green energy as an alternative to fossil fuels, becomes an essential part to build a roadmap towards sustainable energy future [1,2]. Among the green and sustainable energy, hydrogen is a clean energy resource with great abundance and significant energy density, since it can be produced from water without release of carbon dioxide or other toxic products in the process of conversion to other forms of energy. Fossil fuels (such as natural gas, coal, or biomass gasification) are still the main source for producing hydrogen in the current industrial production, occupying $96 \%$ of hydrogen production. Only $4 \%$ is produced through electrolytic water [3-5]. Theoretically, only a potential of $1.23 \mathrm{~V}$ is required for water splitting. However, a high voltage, typically larger than $1.8 \mathrm{~V}$, is needed to trigger the water splitting reaction. Water electrolysis consists of a two-electron transfer cathodic hydrogen evolution reaction (HER) and a four-electron coupled anodic oxygen evolution reaction (OER). The large activation barriers in HER and OER pathways result in large overpotentials, thus leading to slow kinetics of water electrolysis [6-8]. Therefore, we must use electrocatalysts with high activity to reduce the activation energy barrier of HER and OER, lower the overpotential and ultimately achieve a more efficient energy conversion. 
At this stage, research of electrolysis for hydrogen production using freshwater has yielded good results; however, research of seawater electrolysis for hydrogen production is still at the early stage $[9,10]$. The freshwater resource is scarce, most of which remains frozen or in the form of chemosynthetic water. On the contrary, seawater, accounting for $96.5 \%$ of the earth's resources, is world-widely abundant. It is promising to utilize seawater as electrolyte for water electrolysis to produce hydrogen. However, there are up to $3.5 \mathrm{wt} \%$ salts in seawater in presence of different metal ions, which may participate in various competing electrochemical reactions to HER at the cathode, limiting the efficiency of water electrolysis [9-12]. Moreover, the presence of bacteria and microorganisms in natural seawater can lead to the formation of insoluble precipitates on the active site of the catalyst surface, which may affect the HER performance (Figure 1) $[13,14]$. On the other hand, high concentration of chloride ions (ca. $0.5 \mathrm{M}$ ) may block the active center of catalysts [15]. Furthermore, the chlorine evolution reaction (CER) may also occur as a competitive reaction to OER at the anode [16]. Under acidic conditions at $\mathrm{pH}=0$, the theoretical overpotential of four-electron transfer OER (1.23 V vs. SHE) is $130 \mathrm{mV}$ lower than that of two-electron transfer CER, and thus, CER has faster kinetics [17]. Given that the overpotential of CER does not vary with $\mathrm{pH}$ as OER does, the inhibition of CER can be achieved by increasing the alkalinity of the electrolyte. Nevertheless, another reaction occurs in an alkaline environment, namely, the hypochlorite production reaction [18]. Therefore, in order to achieve high-efficiency hydrogen production and realize industrial seawater electrolysis, it is necessary to have a systematic summary and in-depth understanding of the reaction mechanism as well as the related parameters affecting the performance.

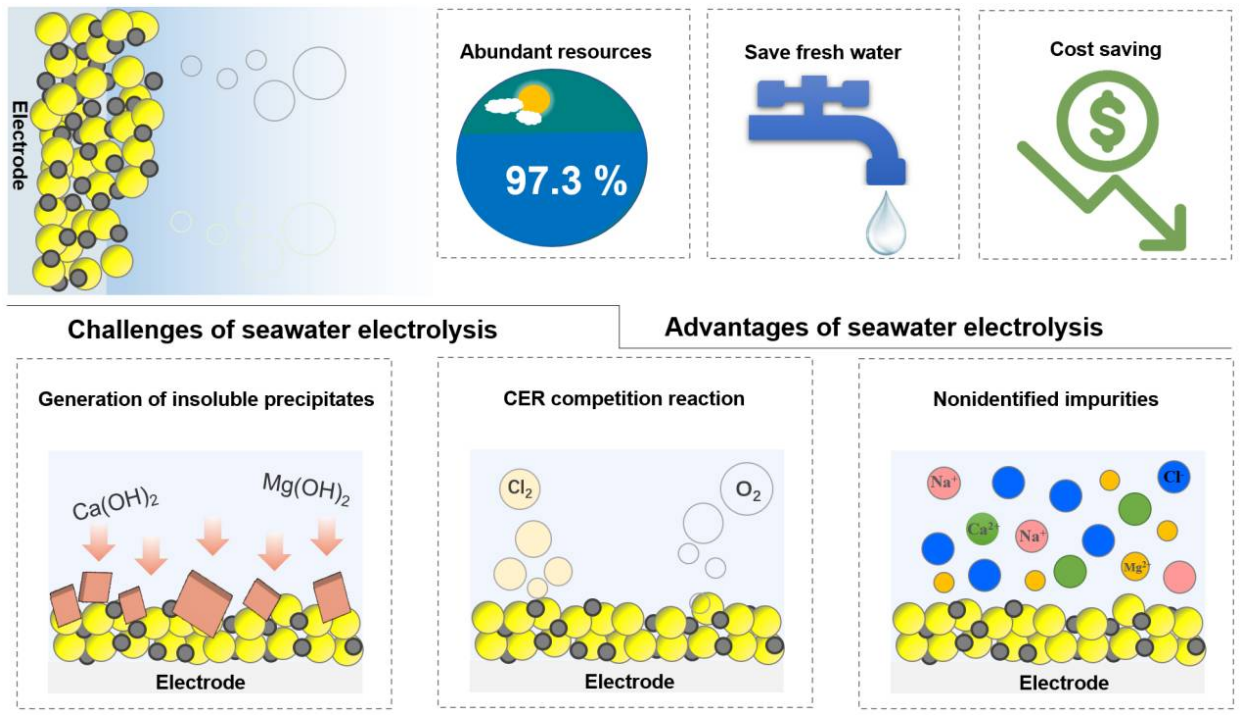

Figure 1. Advantages and challenges of seawater electrolysis.

Up to now, various catalysts have been studied into the seawater electrolysis [9,10,19-32]. Successful examples, such as metal (hydrogen) oxides, nitrides, phosphides, borides, and hybrid catalysts have been applied as catalysts for OER in seawater. In addition to what have been studied for OER, noble metal alloy, carbon-supported noble metals, MXene-based complexes as well as the hybrid materials with different composites or structures have been utilized as catalysts for HER in seawater. All these catalysts have their own merits and demerits in the seawater electrolysis. Therefore, in this review, we provide an overview of recent advances in efficient electrocatalysts for seawater splitting and summarize in detail the current status of research on HER and OER catalysts in seawater electrolysis. Finally, we point out the current challenges for seawater electrolysis and provide possible directions for the future development of seawater electrolysis technology. 


\section{Reaction Mechanism}

\subsection{Mechanism of HER and OER}

Electrolysis of water is a thermodynamically sloping chemical process with a measured Gibbs free energy of approximately $237.2 \mathrm{~kJ} \mathrm{~mol}^{-1}$ [33]. The electrolytic water process consists of anode OER and cathode HER. HER is a two electron transfer process and OER is a four electron transfer process, which respectively produces molecular hydrogen and oxygen through several proton and electron coupling steps [34,35]. The overpotential is the excess potential above the thermodynamic value of $1.23 \mathrm{~V}$ for overall water splitting. As seen from Equations (1)-(4), the decomposition of water can be carried out in different pH environments.

In acidic $\mathrm{pH}$ medium:

$$
\begin{gathered}
\text { Anode : } 2 \mathrm{H}_{2} \mathrm{O}=\mathrm{O}_{2}+4 \mathrm{H}^{+}+4 \mathrm{e}^{-} \\
\text {Cathode : } 2 \mathrm{H}^{+}+2 \mathrm{e}^{-}=\mathrm{H}_{2}
\end{gathered}
$$

In alkaline $\mathrm{pH}$ medium:

$$
\begin{aligned}
& \text { Anode : } 4 \mathrm{OH}^{-}=\mathrm{O}_{2}+2 \mathrm{H}_{2} \mathrm{O}+4 \mathrm{e}^{-} \\
& \text {Cathode : } 2 \mathrm{H}_{2} \mathrm{O}+2 \mathrm{e}^{-}=\mathrm{H}_{2}+2 \mathrm{OH}^{-}
\end{aligned}
$$

\subsection{Characteristics of Seawater Catalytic Reaction}

Compared with freshwater, seawater contains extra salts, which creates complexity in the electrolysis reaction $[9,10]$. The effects of multiple cations and anions in seawater on the water electrolysis are discussed as follows.

\subsubsection{Effects of Complex Cation Components}

Seawater exhibits high ionic conductivity due to the existence of up to $3.5 \mathrm{wt} \%$ salts [36]. Among them, sodium ions $\left(\mathrm{Na}^{+}\right)$, potassium ions $\left(\mathrm{K}^{+}\right)$, calcium ions $\left(\mathrm{Ca}^{2+}\right)$, magnesium ions $\left(\mathrm{Mg}^{2+}\right)$, chloride ions $\left(\mathrm{Cl}^{-}\right)$, and sulfate $\mathrm{SO}_{4}{ }^{2-}$ account for more than $99 \%$ of the total salts of seawater $[37,38]$. In lab-scale research, $3.5 \mathrm{wt} \%$ sodium chloride solution is the most popular electrolyte to mimic the seawater [39-41]. It has also been reported to introduce some $\mathrm{Mg}^{2+}, \mathrm{Ca}^{2+}, \mathrm{K}^{+}$, and $\mathrm{SO}_{4}{ }^{2-}$ to mimic natural seawater [42-47]. The complex ions in seawater can increase the ionic conductivity of seawater; however, they also cause the complexity in the seawater electrolysis. For example, as the $\mathrm{H}^{+}$is consumed, the resulting $\mathrm{OH}^{-}$reacts with $\mathrm{Ca}^{2+}$ and $\mathrm{Mg}^{2+}$ to form insoluble precipitates. The insoluble precipitates on the electrode surface may block the active sites and hinder further reaction $[29,30,48]$.

\subsubsection{Effects of Chloride Ions}

The existence of the chloride ions in seawater can affect both anode and cathode. At the cathode side, chloride ions may inhibit the HER by blocking the active center of the catalysts and thus accelerating the degradation of cathode catalysts in the reaction [49]. At the anode side, significant amounts of chlorine or hypochlorites may be generated, since the chloride ions may undergo reduction reactions competitive to OER [31]. Equations (5) and (6) describe the reduction reactions of chloride ions at the anode $[30,31,50]$.

In acid media:

$$
2 \mathrm{Cl}^{-} \rightarrow \mathrm{Cl}_{2}+2 \mathrm{e}^{-}
$$

In alkaline media:

$$
\mathrm{Cl}^{-}+2 \mathrm{OH}^{-} \rightarrow \mathrm{ClO}^{-}+\mathrm{H}_{2} \mathrm{O}+2 \mathrm{e}^{-}
$$

The reduction reactions of chloride ions experience only two electrons, which may have faster kinetics than the four-electron transfer OER [51-53]. In addition, it can be found from the above equations that the $\mathrm{pH}$ of electrolytes can affect the reduction of chloride 
ions, which can be adjusted to control the anodic reactions in seawater electrolysis. OER is considered to be more favorable at $\mathrm{pH}>7.5$ according to the Pourbaix plot with an overpotential below $480 \mathrm{mV}$ [49]. In this case, catalysts with an overpotential of less than $480 \mathrm{mV}$ prefer to have selective OER at the anode.

\section{Electrocatalysts for Driving Seawater Electrolysis}

\subsection{Electrocatalysts for $O E R$}

As discussed above, the competitive oxidation of chloride ions in seawater not only reduces the efficiency of the OER but also produces chlorine-containing species damaging the electrolyzer and causing environmental issues [54-56]. Consequently, excellent catalysts are needed to enable the selective OER. Up to now, a large number of materials, such transition metal oxides and hydroxides, metal phosphides, metal nitrides, metal borides, and hybrid electrocatalysts, have been explored as selective OER catalysts in seawater electrolysis (Table 1).

Table 1. Summary of OER performance of reported electrocatalysts.

\begin{tabular}{|c|c|c|c|c|c|c|}
\hline Catalyst & Electrolytes & Electrodes & $\begin{array}{c}\text { Overpotential } \\
@ 10 \mathrm{~mA} \mathrm{~cm}^{-2}(\mathrm{mV})\end{array}$ & $\begin{array}{l}\text { Tafel Slope } \\
\left(\mathrm{mV} \mathrm{dec} \mathrm{de}^{-1}\right)\end{array}$ & $\begin{array}{l}\text { Mass Loading } \\
\quad\left(\mathrm{mg} \mathrm{cm}^{-2}\right)\end{array}$ & Ref. \\
\hline $\mathrm{FTO} / \mathrm{NiO}$ & $\begin{array}{c}1.0 \mathrm{M} \\
\mathrm{KOH}+0.5 \mathrm{M} \\
\mathrm{NaCl}\end{array}$ & FTO & 401 & & & [57] \\
\hline $\mathrm{Pb}_{2} \mathrm{Ru}_{2} \mathrm{O}_{7-\mathrm{x}}$ & $0.6 \mathrm{M} \mathrm{NaCl}$ & GCE & 500 & 48 & 0.2 & [58] \\
\hline $\mathrm{Pb}_{2} \mathrm{Ru}_{2} \mathrm{O}_{7-\mathrm{x}}$ & $\begin{array}{l}0.6 \mathrm{M} \mathrm{NaCl}+ \\
0.1 \mathrm{M} \mathrm{NaOH}\end{array}$ & GCE & 200 & 45 & 0.2 & [58] \\
\hline $\mathrm{Co}(\mathrm{OH})_{2}$ & $\begin{array}{c}0.25 \mathrm{M} \\
\mathrm{Mg}\left(\mathrm{ClO}_{4}\right)_{2}\end{array}$ & FTO & & 125 & & [50] \\
\hline $\mathrm{Co}(\mathrm{OH})_{2}$ & $\mathrm{MgCl}_{2}$ & FTO & & 63 & & [50] \\
\hline $\begin{array}{c}\mathrm{Mg} \mid \mathrm{Co}- \\
\mathrm{MnO}_{2} / \mathrm{Co}(\mathrm{OH})_{2}\end{array}$ & $\begin{array}{c}0.25 \mathrm{M} \\
\mathrm{Mg}\left(\mathrm{ClO}_{4}\right)_{2}\end{array}$ & FTO & & 151 & & [50] \\
\hline $\begin{array}{c}\mathrm{Mg} \mid \mathrm{Co}- \\
\mathrm{MnO}_{2} / \mathrm{Co}(\mathrm{OH})_{2}\end{array}$ & $0.25 \mathrm{M} \mathrm{MgCl}_{2}$ & FTO & & 144 & & [50] \\
\hline NiFe-LDH & $\begin{array}{l}1 \mathrm{M} \mathrm{KOH}+ \\
0.5 \mathrm{M} \mathrm{NaCl}\end{array}$ & NF & $227\left(100 \mathrm{~mA} / \mathrm{cm}^{2}\right)$ & & 0.32 & [59] \\
\hline $\mathrm{S}-(\mathrm{Ni}, \mathrm{Fe}) \mathrm{OOH}$ & $\begin{array}{l}1 \mathrm{M} \mathrm{KOH}+ \\
\text { Seawater }\end{array}$ & NF & $300\left(100 \mathrm{~mA} / \mathrm{cm}^{2}\right)$ & & & [19] \\
\hline $\mathrm{S}-(\mathrm{Ni}, \mathrm{Fe}) \mathrm{OOH}$ & $1 \mathrm{M} \mathrm{KOH}$ & NF & $281\left(100 \mathrm{~mA} / \mathrm{cm}^{2}\right)$ & 48.9 & & [19] \\
\hline $\mathrm{Ni}_{2} \mathrm{P}-\mathrm{Fe}_{2} \mathrm{P}$ & $1 \mathrm{M} \mathrm{KOH}$ & NF & $452\left(100 \mathrm{~mA} / \mathrm{cm}^{2}\right)$ & 58 & 15.0 & [60] \\
\hline $\mathrm{Ni}_{2} \mathrm{P}-\mathrm{Fe}_{2} \mathrm{P}$ & $\begin{array}{c}1 \mathrm{M} \mathrm{KOH}+ \\
\text { Seawater }\end{array}$ & NF & $581\left(100 \mathrm{~mA} / \mathrm{cm}^{2}\right)$ & & 15.0 & {$[60]$} \\
\hline $\mathrm{Co}-\mathrm{Fe}_{2} \mathrm{P}$ & $1 \mathrm{M} \mathrm{KOH}$ & NF & $274\left(100 \mathrm{~mA} / \mathrm{cm}^{2}\right)$ & 45 & 2.0 & [61] \\
\hline $\mathrm{Co}-\mathrm{Fe}_{2} \mathrm{P}$ & $\begin{array}{c}1 \mathrm{M} \mathrm{KOH}+0.5 \mathrm{M} \\
\mathrm{NaCl}\end{array}$ & NF & $460\left(100 \mathrm{~mA} / \mathrm{cm}^{2}\right)$ & & 2.0 & [61] \\
\hline Ti@NiB & $\underset{\mathrm{NaCl}}{1 \mathrm{M} \mathrm{KOH}+0.5 \mathrm{M}}$ & Ti plate & $397\left(50 \mathrm{~mA} / \mathrm{cm}^{2}\right)$ & 34.2 & 3.2 & [62] \\
\hline $\mathrm{Co}-\mathrm{Fe}-\mathrm{O}-\mathrm{B}$ & $\begin{array}{c}1 \mathrm{M} \mathrm{KOH}+0.5 \mathrm{M} \\
\mathrm{NaCl}\end{array}$ & GCE & 294 & & 0.1 & [23] \\
\hline $\begin{array}{l}\text { multilayered } \\
\text { NiFeBx }\end{array}$ & $\begin{array}{c}1 \mathrm{M} \mathrm{KOH}+0.5 \mathrm{M} \\
\mathrm{NaCl}\end{array}$ & & $263 \pm 14$ & & & [63] \\
\hline NiMoN@NiFeN & $\begin{array}{c}1 \mathrm{M} \mathrm{KOH}+ \\
\text { Seawater }\end{array}$ & NF & $369\left(500 \mathrm{~mA} / \mathrm{cm}^{2}\right)$ & & & [18] \\
\hline $\mathrm{Fe}-\mathrm{Ni}(\mathrm{OH})_{2} / \mathrm{Ni}_{3} \mathrm{~S}_{2}$ & $\begin{array}{c}1 \mathrm{M} \mathrm{KOH}+0.5 \mathrm{M} \\
\mathrm{NaCl}\end{array}$ & NF & 269 & 46 & & [64] \\
\hline $\mathrm{CoP}_{x} @ \mathrm{FeOOH}$ & $\begin{array}{l}1 \mathrm{M} \mathrm{KOH} \\
\text { Seawater }\end{array}$ & NF & $283\left(100 \mathrm{~mA} / \mathrm{cm}^{2}\right)$ & & 1.82 & [24] \\
\hline
\end{tabular}




\subsubsection{Metal Oxides and Hydroxides for OER}

Metal oxides and hydroxides are widely used as OER catalysts due to their high catalytic activity and efficiency [65-68]. In 1998, Izumiya et al. investigated the effect of anodic deposited manganese oxide and manganese oxide-OER efficiency on tungsten electrodes [69]. Particular attention was paid to the effect of $\mathrm{pH}$ and tungsten content in the oxide of the anodically deposited electrode on the efficiency of the OER. Manganesemolybdenum oxide electrodes with sufficient thickness of oxides prepared via anodic deposition on an $\mathrm{IrO}_{2}$-coated substrate by Fujimura et al. delivered an OER efficiency of approximately $100 \%$ at pH 12 in $0.5 \mathrm{M} \mathrm{NaCl}$ [70]. The MnMo double oxide $\left(\mathrm{Mn}_{1-\mathrm{x}} \mathrm{Mo}_{\mathrm{x}} \mathrm{O}_{2+\mathrm{x}}\right)$ prepared by Abdel Ghany et al. [71] delivered an OER efficiency close to $100 \%$ in a $0.5 \mathrm{M} \mathrm{NaCl}$ solution. However, as the temperature increased, the MnMo double oxides gradually turned into permanganate and molybdate ions. Therefore, iron was added to $\mathrm{Mn}_{1-\mathrm{x}} \mathrm{Mo}_{\mathrm{x}} \mathrm{O}_{2+\mathrm{x}}$ in order to improve the stability of the catalysts at high temperatures. Later, El-Moneim et al. [21] reported $\mathrm{IrO}_{2} /$ Ti supported Mn-Mo-W triple oxide catalysts. The addition of tungsten played its role by increasing the electrical conductivity of the oxide deposition, which improved the OER efficiency of the anode.

Another type of metal oxides active for $\mathrm{OER}, \mathrm{NiFeO}_{x}$ usually has significant activity under alkaline conditions, in which the presence of Fe is the key to improving the performance [72,73]. However, the reason for Fe doping to enhance OER kinetics remains controversial. Highly active $\mathrm{NiFeO}_{x}$ electrocatalysts are gradually deactivated over time during catalysis due to the loss of Fe elements from the active sites into solution [20]. Obata et al. [20] used the anodic deposition of the $\mathrm{CeO}_{\mathrm{x}}$ layer to prevent the loss of $\mathrm{Fe}$, so as to achieve high activity and stability of the catalyst. The $\mathrm{CeO}_{x}$ layer effectively prevented the diffusion of redox ions through the layer, but nevertheless, it allowed $\mathrm{OH}^{-}$and $\mathrm{O}_{2}$ to pass through without affecting the performance of the catalyst.

Under simulated alkaline seawater conditions, $\mathrm{Pb}_{2} \mathrm{Ru}_{2} \mathrm{O}_{7-x}$ (Figure 2a,b) was found to have better performance than its neutral electrocatalysts in terms of OER selectivity, activity, and stability (Figure 2c) [58]. The selectivity, activity, and stability of $\mathrm{RuO}_{2}$ were found to be much lower under alkaline and neutral simulated seawater conditions compared to $\mathrm{Pb}_{2} \mathrm{Ru}_{2} \mathrm{O}_{7-\mathrm{x}}$. The higher oxidation state on the ruthenium surface and the large number of oxygen vacancies in $\mathrm{Pb}_{2} \mathrm{Ru}_{2} \mathrm{O}_{7-x}$ exhibited excellent OER selective electrocatalytic activity. Optimizing the efficiency of OER in acidic media is particularly difficult, and many efforts have been devoted. Koper et al. [22] electrodeposited $\mathrm{MnO}_{\mathrm{x}}$ films on a glassy carbon electrode loaded with iridium oxide at $\mathrm{pH} \sim 0.9$ in aqueous solution containing chloride ions. The deposition of $\mathrm{MnO}_{\mathrm{x}}$ on $\mathrm{IrO}_{\mathrm{x}}$ reduced the CER selectivity in the presence of $30 \mathrm{mM} \mathrm{Cl}^{-}$ from $86 \%$ to less than $7 \%$.

Electrolysis in seawater environment, the corrosion caused by chloride ions, is an important issue. Juodkazyte et al. [57] proposed to form a nickel oxide layer on a conductive glass substrate, which showed excellent corrosion resistance in chloride solution. Okada et al. also prepared bilayer structured films with a top layer $\left(\mathrm{Mg}^{2+}\right.$ intercalated Co- $\left.-\mathrm{MnO}_{2}\right)$ and a bottom layer $\left(\alpha-\mathrm{Co}(\mathrm{OH})_{2}\right)($ Figure $2 \mathrm{~d}-\mathrm{f})[50]$. The Co- $\mathrm{MnO}_{2}$ acted as a protective coating which was not catalytically active; however, it allowed $\mathrm{H}_{2} \mathrm{O}$ to penetrate into the active catalytic sites of the $\mathrm{Co}(\mathrm{OH})_{2}$ and expelled chloride ions at the same time. In a $\mathrm{MgCl}_{2}$ solution without ion exchange, $\mathrm{Mg} \mid \mathrm{CoMnO}_{2} / \mathrm{Co}(\mathrm{OH})_{2}$ showed a significant selectivity and the highest activity for OER in the presence of $\mathrm{Cl}^{-}$(Figure 2g,h). 
(a)

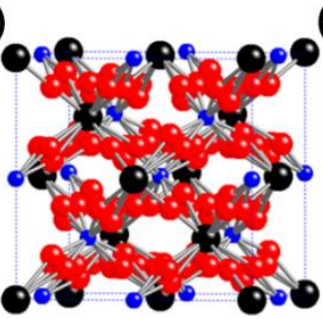

(d)
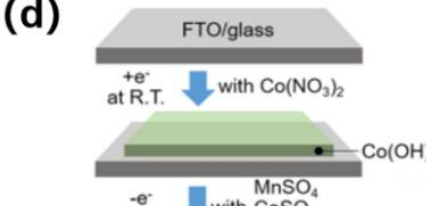

at $70^{\circ} \mathrm{C}$
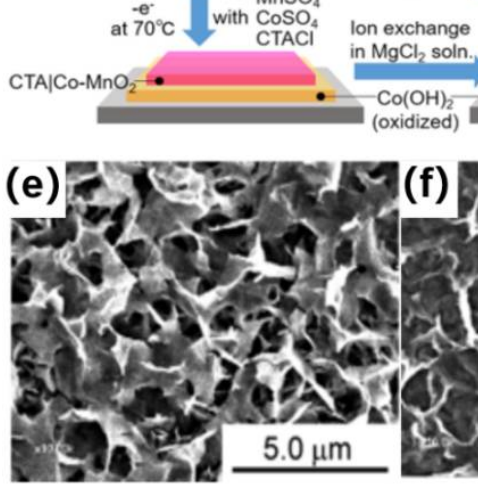

(b)

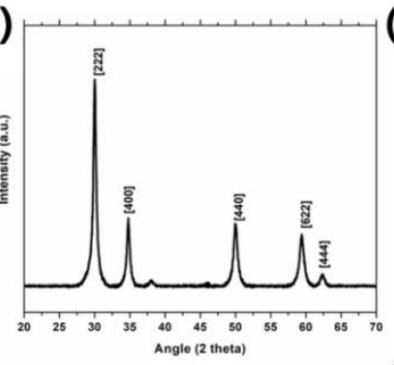

(c)

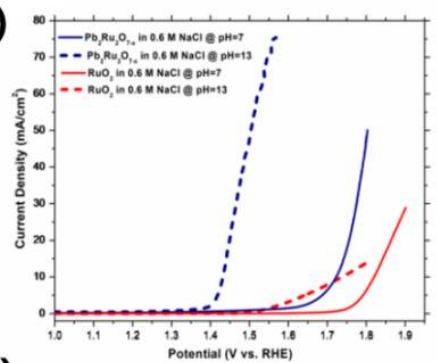

(g)

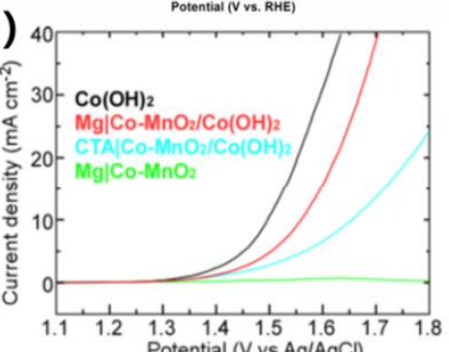

(h)

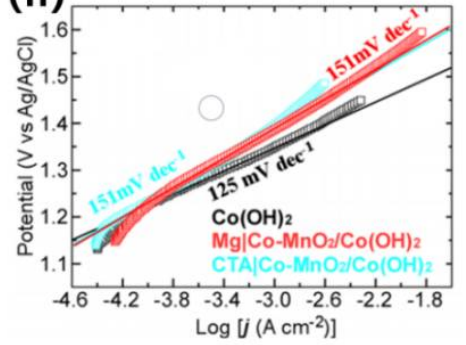

Figure 2. (a) Crystal structure of $\mathrm{Pb}_{2} \mathrm{Ru}_{2} \mathrm{O}_{7-\mathrm{x}}$, (b) XRD of $\mathrm{Pb}_{2} \mathrm{Ru}_{2} \mathrm{O}_{7-\mathrm{x}}$, and (c) LSV curves of $\mathrm{Pb}_{2} \mathrm{Ru}_{2} \mathrm{O}_{7-\mathrm{x}}$ and $\mathrm{RuO}_{2}$. Reproduced with permission from [58]. Copyright (C 2020 American Chemical Society, (d) Schematic representation of $\mathrm{Mg} \mid \mathrm{CoMnO}_{2} / \mathrm{Co}(\mathrm{OH})_{2}$ bilayer structure, $(\mathbf{e}, \mathbf{f})$ SEM images of $\mathrm{Co}(\mathrm{OH})_{2}$ and CTA I Co- $\mathrm{MnO}_{2} / \mathrm{Co}(\mathrm{OH})_{2}$, and $(\mathbf{g}$, h) LSV curves and the corresponding Tafel plots for the relevant films. Reproduced with permission from [50]. Copyright (C) 2020, American Chemical Society.

In addition to metal oxides, metal hydroxides are a kind of catalysts widely used for OER, which even surpassed $\mathrm{IrO}_{2}$ in some cases [72]. However, the majority of hydroxide catalysts suffer from low conductivity and chloride corrosion, unable to meet further industrial demand for the electrolysis of seawater. Layered double hydroxides (LDHs) are one of the most reported metal hydroxide catalysts. NiFe-LDHs with partially crystalline and highly crystalline structures were recently reported for efficient OER [59]. It was found that the OER performance of partially crystalline NiFe-LDH was superior to its highly crystalline counterpart. Yu et al. [19] reported a S-doped Ni/Fehydroxide catalyst (S-(Ni,Fe)OOH), which exhibited extraordinary OER performance in both alkaline brine and seawater electrolytes. In the seawater electrolyte with $1 \mathrm{M} \mathrm{KOH}$, the overpotentials of $\mathrm{S}-(\mathrm{Ni}, \mathrm{Fe}) \mathrm{OOH}$ were 300 and $398 \mathrm{mV}$ at current densities of 100 and $500 \mathrm{~mA} \mathrm{~cm}^{-2}$, respectively. Liu et al. used $\mathrm{Zr}$ doped CoFe-LDH/NF to prepare highly active OER catalysts [74]. The results showed that the addition of $\mathrm{Zr}^{4+}$ reduced the crystallinity and expanded the active surface area. $\mathrm{CoOOH}$ intermediate produced on the surface not only improved the OER activity but also prevented the $\mathrm{Cl}^{-}$adsorption. In $1 \mathrm{M} \mathrm{KOH}+0.5 \mathrm{M} \mathrm{NaCl}$ electrolyte, when the current density reached $100 \mathrm{~mA} \mathrm{~cm}^{-2}$, the overpotential of the electrocatalyst was only $303 \mathrm{mV}$.

\subsubsection{Metal Phosphides for OER}

Metal phosphides have attracted much attention in recent years because of their good conductivity, stability, and metal-atom coordination effects [75,76]. Metal phosphides have a similar structure to hydrogenase, in which the metal site and P site can be used as proton receptor and hydrogenation receptor center, respectively [29]. Wu et al. [60] synthesized 
$\mathrm{Ni}_{2} \mathrm{P}-\mathrm{Fe}_{2} \mathrm{P}$ by immersing nickel foam in hydrochloric acid and ferric nitrate solution and phosphating (Figure $3 \mathrm{a}$ ). $\mathrm{Ni}_{2} \mathrm{P}-\mathrm{Fe}_{2} \mathrm{P}$ has excellent activity in seawater electrolysis due to its fast electron transfer rate, corrosion resistance, and hydrophilicity (Figure $3 b-d$ ). The overpotentials of $\mathrm{Ni}_{2} \mathrm{P}-\mathrm{Fe}_{2} \mathrm{P}$ in $1 \mathrm{M} \mathrm{KOH}$ seawater were 581 and $774 \mathrm{mV}$ at the current densities of 100 and $500 \mathrm{~mA} \mathrm{~cm}^{-2}$, respectively (Figure $\left.3 \mathrm{e}, \mathrm{f}\right)$. Cobalt-doped $\mathrm{Fe}_{2} \mathrm{P}\left(\mathrm{Co}-\mathrm{Fe}_{2} \mathrm{P}\right)$ was tested by Wang et al. [61] in a simulated seawater electrolyte containing $0.5 \mathrm{M} \mathrm{NaCl}$ and 1.0 M KOH, which showed an overpotential of $460 \mathrm{mV}$ at $100 \mathrm{~mA} \mathrm{~cm}^{-2}$ as well as an excellent electrochemical durability of $22 \mathrm{~h}$ operation.
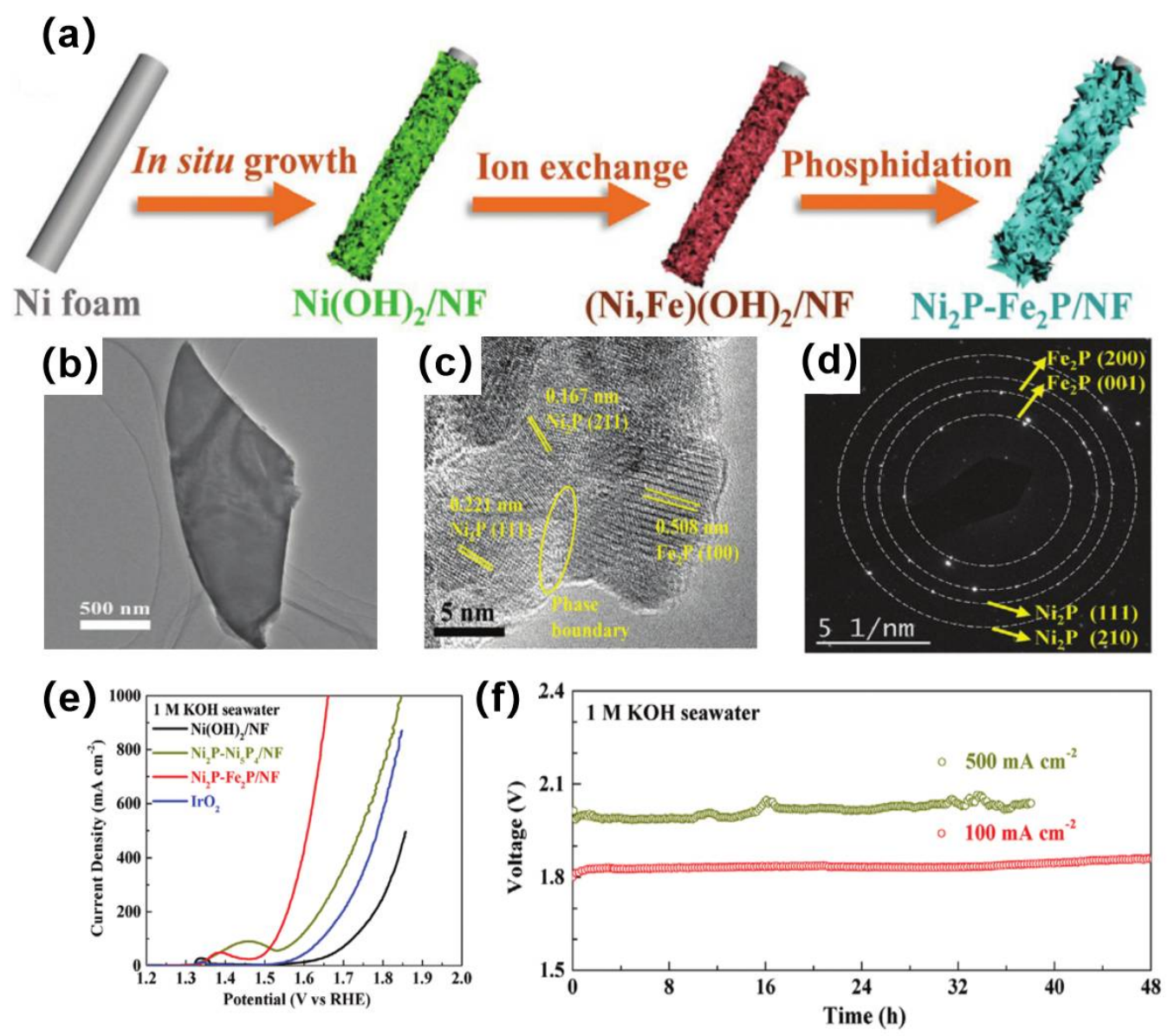

Figure 3. (a) Synthesis diagram of $\mathrm{Ni}_{2} \mathrm{P}-\mathrm{Fe}_{2} \mathrm{P} / \mathrm{NF}$, (b)TEM, (c) HRTEM images, (d) SAED pattern of a slice of a $\mathrm{Ni}_{2} \mathrm{P}-\mathrm{Fe}_{2} \mathrm{P}$ microsheet, (e) OER LSV curves, and (f) chronopotentiometric curves of $\mathrm{Ni}_{2} \mathrm{P}-\mathrm{Fe}_{2} \mathrm{P} / \mathrm{NF}$. Reproduced with permission from [60], Copyright $@$ 2020, Wiley-VCH GmbH.

\subsubsection{Metal Nitrides for OER}

Metal nitrides are of interest in electrocatalysis as an interstitial alloy because of its superior corrosion resistance, good conductivity, strong stability, and remarkable mechanical strength $[77,78]$. The density of states in the d-band of the transition metal can be altered by the introduction of nitrogen atoms. The introduction of nitrogen reduces the d-band density, exhibiting a higher catalytic activity than the original metal materials [79]. Among the metal nitrides, $\mathrm{Ni}_{3} \mathrm{~N} / \mathrm{Ni}, \mathrm{NiMoN}$, and $\mathrm{NiFeMoN}$ are mostly reported catalysts for their remarkable catalytic performance [80-82]. In order to prepare large active surface area and abundant active sites catalysts, Yu et al. [18] prepared a three-dimensional core-shell NiMoN@NiFeN consisting of NiFeN on NiMoN nanorods uniformly modified on a nickel foam carrier (Figure 4a-d). This catalyst showed overpotentials of 369 and $398 \mathrm{mV}$ at current densities of 500 and $1000 \mathrm{~mA} \mathrm{~cm}^{-2}$ in natural seawater with $1 \mathrm{M} \mathrm{KOH}$, respectively. In situ evolution occurred at the anode surface, and the resulting $\mathrm{NiFe}$ oxide and $\mathrm{NiFe}$ hydroxide amorphous layers were the true active sites. In addition, the three-dimensional 
core-shell NiMoN@NiFeN possessed multiple layers of pores, providing an abundance of active sites, allowing efficient charge transfer and accelerated gas release. As a result, NiMoN@NiFeN not only had significant OER performance but was also effective in preventing chlorine corrosion. Furthermore, by coupling NiMoN@NiFeN and NiMoN as anode and cathode catalysts, an excellent two-electrode seawater electrolyzer can be produced (Figure 4e,f). In alkaline natural seawater, the minimum voltage of this electrolyzer was only $1.608 \mathrm{~V}$ at a current density of $500 \mathrm{~mA} \mathrm{~cm}^{-2}$.
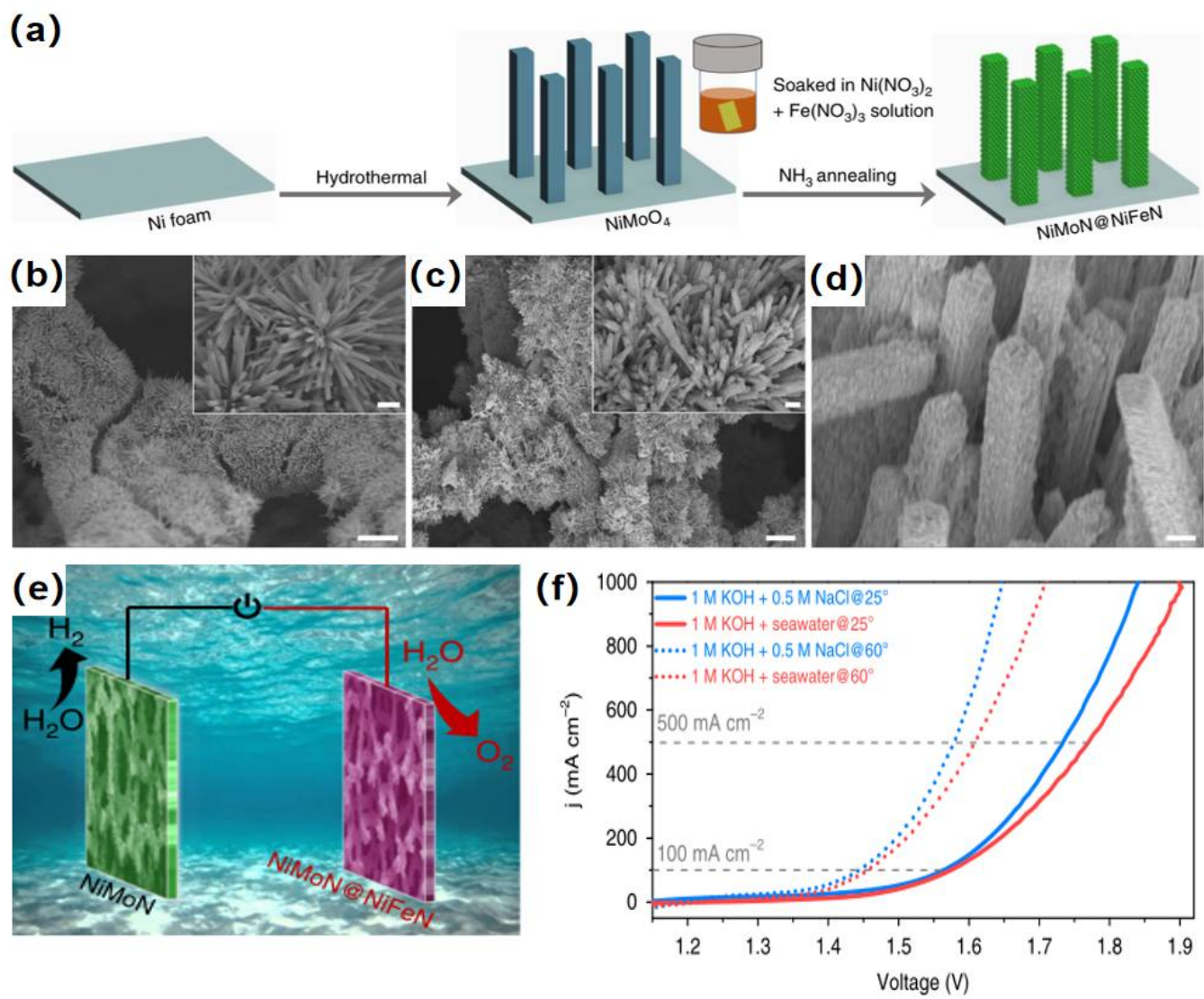

Figure 4. (a) Schematic diagram of the synthesis of NiMoN@NiFeN, (b) SEM images of NiMoN, (c,d) SEM images of NiMoN@NiFeN, (e) schematic diagram of an electrolyzer using NiMoN and NiMoN@NiFeN as catalysts, and (f) LSV curves of NiMoN and NiMoN@NiFeN. Reproduced with permission from [18]. Copyright @ 2019, Springer Nature.

\subsubsection{Metal Borides for OER}

Metal borides are one of the most promising catalysts for OER in seawater electrolytes due to their low cost, high activity, and good stability [83,84]. Recently, Zhang et al. used an electroless plating method to prepare Ti@NiB electrodes on titanium plates [62] and test the OER performance for different electroless plating time $(1,1.5$, and $2 \mathrm{~h})$ in an alkaline seawater electrolyte. Ti@NiB-1.5 h showed the best activity and stability with an overpotential of only $397 \mathrm{mV}$ at a current density of $50 \mathrm{~mA} \mathrm{~cm}^{-2}$. The good catalytic activity and stability of Ti@NiB was attributed to the high active surface area of the modified amorphous $\mathrm{NiB}$ and the good attachment between the catalyst and titanium plate. Compared to monometallic borides, bimetallic borides generally have superior activity and stability [85]. For example, Gupta et al. used hydrothermal method to prepare cobalt-iron bimetallic oxyboride (Co-Fe-O-B) nanostructures with various iron contents [23]. The catalysts were tested in an electrolyte containing $1 \mathrm{M} \mathrm{KOH}$ and $0.5 \mathrm{M} \mathrm{NaCl}$ and delivered an overpotential as low as $294 \mathrm{mV}$ at a current density of $10 \mathrm{~mA} \mathrm{~cm}^{-2}$. The high activity of the catalysts was ascribed to the $\mathrm{Co}_{3} \mathrm{O}_{4}$-core- $\mathrm{Co}_{2} \mathrm{~B}$ shell structure, which favored the formation of active $\mathrm{CoOOH}$ at lower potentials. In addition, $\mathrm{Li}$ et al. also reported a 
NiFe alloy plate electrode synthesized by thermal boronization with boron powder followed by electrochemical oxidation [63]. The catalytically active layer, the anti-corrosion layer, and the structural support of this multilayer electrode are the surface oxidized NiFeBx alloy layer, the NiFeBx alloy interlayer, and the NiFe alloy substrate, respectively. The presence of the outermost oxidized NiFeBx layer facilitates the generation of the catalytically active phase $\gamma-(\mathrm{Ni}, \mathrm{Fe}) \mathrm{OOH}$, while the NiFeBx interlayer facilitates the prevention of corrosion of the anode material. In $1 \mathrm{M} \mathrm{KOH}+0.5 \mathrm{M} \mathrm{NaCl}$ electrolyte, the multilayer electrode not only had little change in overpotential, and the stability tests lasted for over $70 \mathrm{~h}$.

\subsubsection{Hybrid Electrocatalysts for OER}

According to previous studies, hybrid structured catalysts usually show significant activity in seawater electrolysis. In contrast to single metal materials, the two components of a hybrid structured catalyst can create a synergistic effect, resulting in a mixed charge distribution and improved electrocatalytic performance [86,87]. For example, Cui et al. [64] prepared a heterostructured catalyst consisting of $\mathrm{Fe}-\mathrm{Ni}(\mathrm{OH})_{2}$ nanosheets and $\mathrm{Ni}_{3} \mathrm{~S}_{2}$ nanoarrays, which exposed abundant active sites for OER in alkaline seawater electrolyte (Figure 5a-e). When the current density was $10 \mathrm{~mA} \mathrm{~cm}^{-2}$, the overpotential was as low as $269 \mathrm{mV}$, and the Tafel slope was only $46 \mathrm{mV} \mathrm{dec}^{-1}$. In addition, it also shows significant stability after $27 \mathrm{~h}$ operation at a high current density of $100 \mathrm{~mA} \mathrm{~cm}^{-2}$ with a Faraday efficiency as high as $95 \%$. The catalytic performance of $\mathrm{FeNi}(\mathrm{OH})_{2} / \mathrm{Ni}_{3} \mathrm{~S}_{2}$ catalyst may benefit from the introduction of iron activator, which provides a large number of heterostructures with active and selective sites. In addition, Wu et al. [24] constructed the core-shell structure of $\mathrm{CoP}_{\mathrm{x}} @ \mathrm{FeOOH}$ with a multiphase cobalt phosphide $\left(\mathrm{CoP}_{\mathrm{x}}, \mathrm{CoP}-\mathrm{CoP}_{2}\right)$ core (Figure $\left.5 \mathrm{f}\right)$. Synergistic effects were yielded by integrating the highly conductive $\mathrm{CoP}_{x}$ core into the active $\mathrm{FeOOH}$ shell, showing high conductivity, large surface area, and increased turnover frequency. $\mathrm{CoP}_{x}$ core with negative charges modulated the adsorption energy between the $\mathrm{OOH}$ active species and the OER intermediates, finally enhancing the catalytic activity of the catalyst. In the seawater electrolyte with $1 \mathrm{M} \mathrm{KOH}$, the overpotential was as low as $283 \mathrm{mV}$ at a current density of $100 \mathrm{~mA} \mathrm{~cm}{ }^{-2}$ and only $337 \mathrm{mV}$ at a current density of $500 \mathrm{~mA} \mathrm{~cm}{ }^{-2}$. Excellent stability over $80 \mathrm{~h}$ was also achieved, without generation of any hypochlorite.

(a)

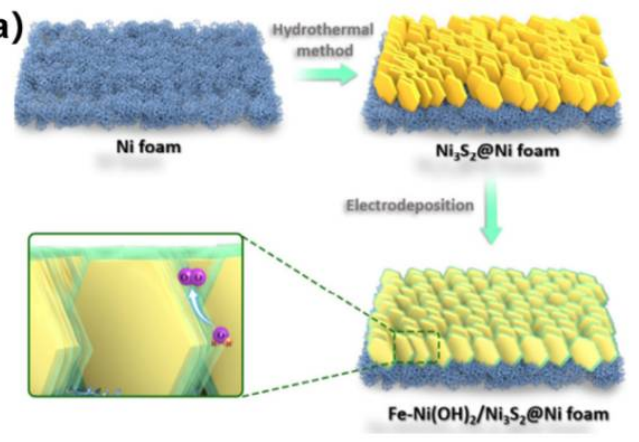

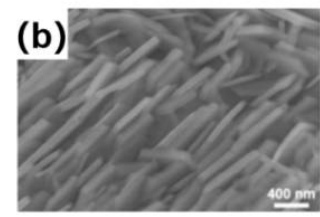

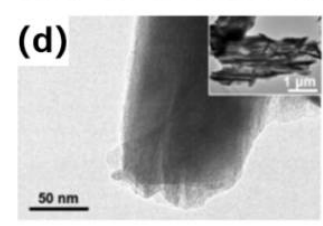

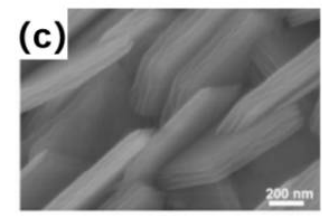

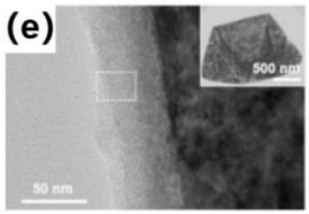

(f)

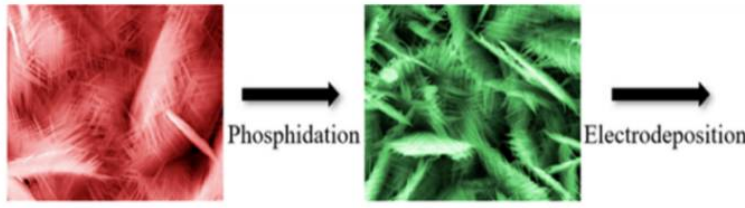

$\mathrm{Co}(\mathrm{OH})_{2}$

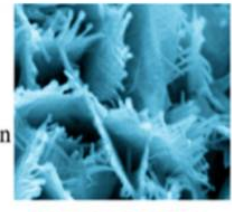

$\mathrm{CoP}_{\mathrm{x}} @ \mathrm{FeOOH}$

Figure 5. (a) Schematic illustration for the synthesis of $\mathrm{Fe}-\mathrm{Ni}(\mathrm{OH})_{2} / \mathrm{Ni}_{3} \mathrm{~S}_{2}$, (b,c) SEM images of $\mathrm{Fe}-\mathrm{Ni}(\mathrm{OH})_{2} / \mathrm{Ni}_{3} \mathrm{~S}_{2}$, (d,e) TEM images of the lateral edge at a vertical plate. Reproduced with permission from [64]. Copyright (C) 2020, Springer Nature, (f) Schematic illustration of the synthesis of $\mathrm{CoP}_{\mathrm{x}} @ \mathrm{FeOOH}$. Reproduced with permission from [24]. Copyright (C 2021, Elsevier. 
In summary, there have been successful examples of metal (hydrogen) oxides, nitrides, phosphides, borides as well as hybrid catalysts in seawater electrolysis reactions. All these catalysts have their own characteristics in seawater electrolysis. Metal oxides usually have low price and strong stability [70]. Metal hydroxides are characterized by their low cost, high catalytic efficiency, and their unique layered structure which provides a larger active surface area [19]. Metal oxides and hydroxides are the most widely used OER catalysts, but their intrinsic low electrical conductivity is a major challenge. Metal nitrides have recently become one of the most intensively studied OER catalysts because of their excellent corrosion resistance, low resistance, and high melting point [18]. Compared with oxides and hydroxides, metal phosphides usually have stronger conductivity, in addition to their excellent stability [61]. In terms of metal borides, they usually show excellent catalytic activity and stability in OER. Moreover, the metal boride layer is also conducive to preventing the corrosion of anode materials in seawater [88]. To fully utilize the advantages of different materials, hybrid catalysts combined with different materials or structures are receiving increasing attention.

\subsection{Electrocatalysts for HER}

Previous studies have shown few competitive reactions to the HER in seawater electrolytes, unlike those in the anode compartment. However, the main problem of cathodic HER is the presence of impurities in seawater, which leads to blockage and corrosion of the active sites, resulting in low efficiency and poor stability [89]. At this stage, mostly reported electrocatalysts for HER in seawater electrolysis include noble metal alloys, carbonsupported noble metals, MXene based complexes, metal phosphides, metal oxides, metal hydroxides, metal nitrides, hybrid electrocatalysts, and so on (Table 2).

Table 2. Summary of HER performance of reported electrocatalysts.

\begin{tabular}{|c|c|c|c|c|c|c|c|c|}
\hline Catalyst & Eectrode & Electrolytes & $\begin{array}{c}\text { Onset } \\
\text { Potential } \\
(\mathrm{mV})\end{array}$ & $\begin{array}{c}\text { Overpotential } \\
@ 10 \mathrm{~mA} \mathrm{~cm}^{-2} \\
(\mathrm{mV})\end{array}$ & $\begin{array}{l}\text { Tafel Slope } \\
\left(\mathrm{mV} \mathrm{dec}^{-1}\right)\end{array}$ & $\begin{array}{l}\text { Exchange } \\
\text { Current } \\
\text { Density } \\
\left(\mathrm{mA} \mathrm{cm}^{-2}\right)\end{array}$ & $\begin{array}{c}\text { Mass } \\
\text { Loading } \\
\left(\mathrm{mg} \mathrm{cm}^{-2}\right)\end{array}$ & Ref. \\
\hline $\mathrm{Pt}$ & Ti mesh & seawater & 151.80 & 285 & 45.8 & $7.336 \times 10^{-5}$ & & [25] \\
\hline $\mathrm{Pt}-\mathrm{Ru}-\mathrm{Cr}$ & Ti mesh & seawater & 129.89 & 256 & 45.7 & $9.280 \times 10^{-5}$ & & [25] \\
\hline Pt-Ru-Fe & Ti mesh & seawater & 125.92 & 248 & 45.2 & $9.337 \times 10^{-5}$ & & [25] \\
\hline $\mathrm{Pt}-\mathrm{Ru}-\mathrm{Co}$ & Ti mesh & seawater & 112.79 & 222 & 44.8 & $9.339 \times 10^{-5}$ & & [25] \\
\hline Pt-Ru-Ni & Ti mesh & seawater & 103.25 & 206 & 44.5 & $1.006 \times 10^{-4}$ & & [25] \\
\hline Pt-Ru-Mo & Ti mesh & seawater & 96.22 & 196 & 44.0 & $1.080 \times 10^{-4}$ & & [25] \\
\hline $\mathrm{Pt} / \mathrm{C}$ & GCE & seawater & 185 & & 59 & $1.05 \times 10^{-4}$ & 0.199 & [90] \\
\hline $\mathrm{PtNi}_{5}$ & GCE & seawater & 380 & & 119 & $8.51 \times 10^{-5}$ & 0.199 & [90] \\
\hline $\mathrm{PtCr}_{0.1}$ & Ti mesh & seawater & 166.03 & 283.8 & & $3.90 \times 10^{-5}$ & & [26] \\
\hline $\mathrm{PtFe}_{0.1}$ & Ti mesh & seawater & 157.69 & 275.2 & & $4.55 \times 10^{-5}$ & & [26] \\
\hline $\mathrm{PtCo}_{0.1}$ & Ti mesh & seawater & 149.93 & 266.5 & & $5.18 \times 10^{-5}$ & & [26] \\
\hline $\mathrm{PtNi}_{0.1}$ & Ti mesh & seawater & 147.75 & 263.3 & & $5.27 \times 10^{-5}$ & & [26] \\
\hline $\mathrm{PtMo}_{0.1}$ & Ti mesh & seawater & 142.50 & 254.6 & & $5.35 \times 10^{-5}$ & & [26] \\
\hline $\mathrm{Ti} / \mathrm{NiPt}$ & Ti foil & seawater & 230 & & 111 & $9.59 \times 10^{-3}$ & & [91] \\
\hline $\mathrm{Ti} / \mathrm{NiAu}$ & Ti foil & seawater & 410 & & 170 & $3.35 \times 10^{-3}$ & & [91] \\
\hline RuCo & Ti foil & seawater & 253 & & 107 & $4.71 \times 10-^{3}$ & & [36] \\
\hline $\mathrm{RuCoMo}_{1}$ & Ti foil & seawater & 354 & & 137 & $2.69 \times 10^{-3}$ & & [36] \\
\hline NiRuIr_G & & seawater & & 80 & 48 & & & [92] \\
\hline 0.5Rh-G1000 & GCE & $1 \mathrm{M}$ PBS & & 250 & & & 1.0 & [93] \\
\hline $0.5 R h-G 1000$ & GCE & seawater & & 340 & & & 1.0 & [93] \\
\hline 0.5Rh-GS1000 & GCE & $1 \mathrm{M}$ PBS & & 19 & & & 1.0 & [93] \\
\hline $\begin{array}{c}0.5 \mathrm{Rh}-\mathrm{GS} 1000 \\
2.4 \%\end{array}$ & GCE & seawater & & 320 & & & 1.0 & [93] \\
\hline $\begin{array}{c}\text { Pt@mh-3D } \\
\text { MXene }\end{array}$ & GCE & seawater & & 280 & & & 0.2 & [94] \\
\hline
\end{tabular}


Table 2. Cont.

\begin{tabular}{|c|c|c|c|c|c|c|c|c|}
\hline Catalyst & Eectrode & Electrolytes & $\begin{array}{c}\text { Onset } \\
\text { Potential } \\
(\mathrm{mV})\end{array}$ & $\begin{array}{c}\text { Overpotential } \\
@ 10 \mathrm{~mA} \mathrm{~cm}^{-2} \\
(\mathrm{mV})\end{array}$ & $\begin{array}{l}\text { Tafel Slope } \\
(\mathrm{mV} \mathrm{dec}-1)\end{array}$ & $\begin{array}{l}\text { Exchange } \\
\text { Current } \\
\text { Density } \\
\left(\mathrm{mA} \mathrm{cm}^{-2}\right)\end{array}$ & $\begin{array}{c}\text { Mass } \\
\text { Loading } \\
\left(\mathrm{mg} \mathrm{cm}^{-2}\right)\end{array}$ & Ref. \\
\hline $\mathrm{VS}_{2} @ \mathrm{~V}_{2} \mathrm{C}$ & GCE & $\begin{array}{l}\text { seawater } \\
(\mathrm{PH}=0)\end{array}$ & & $\begin{array}{c}148 \\
\left(20 \mathrm{~mA} \mathrm{~cm}^{-2}\right)\end{array}$ & 37 & & 27.55 & [27] \\
\hline $\begin{array}{l}\text { h-MoN@ } \\
\text { BNCNT }\end{array}$ & GCE & seawater & & & 128 & & 0.254 & [95] \\
\hline $\mathrm{NiCoP} / \mathrm{NF}$ & NF & seawater & & $287 \mathrm{mV}$ & & & 2.0 & [96] \\
\hline $\begin{array}{l}\text { PSS-PPy/ } \\
\text { Ni-Co-P }\end{array}$ & $\mathrm{CF}$ & $\begin{array}{l}\text { artificial } \\
\text { seawater }\end{array}$ & & 144 & & & & [97] \\
\hline $\mathrm{C}-\mathrm{Co}_{2} \mathrm{P}$ & GCE & $\begin{array}{c}1 \mathrm{M} \mathrm{KOH} \\
1 \mathrm{M} \mathrm{KOH} \\
0.5 \mathrm{M} \mathrm{NaCl} \\
41.2 \times 10^{-3}\end{array}$ & & 100 & & & 2.18 & [28] \\
\hline $\mathrm{C}-\mathrm{Co}_{2} \mathrm{P}$ & GCE & $\begin{array}{c}\mathrm{M} \mathrm{MgCl}_{2} \\
\text { and } 12.5 \times \\
10^{-3} \mathrm{M} \\
\mathrm{CaCl}_{2}\end{array}$ & & $\begin{array}{c}192 \\
\left(1000 \mathrm{~mA} \mathrm{~cm}^{-2}\right)\end{array}$ & & & 2.18 & [28] \\
\hline $\mathrm{Ru}-\mathrm{CoOx}$ & $\mathrm{NF}$ & $\begin{array}{c}1 \mathrm{M} \mathrm{KOH}+ \\
\text { seawater }\end{array}$ & & $\begin{array}{c}630 \\
\left(100 \mathrm{~mA} \mathrm{~cm}^{-2}\right)\end{array}$ & & & & [98] \\
\hline $\mathrm{Mo}_{5} \mathrm{~N}_{6}$ & GCE & $1 \mathrm{M} \mathrm{KOH}$ & & 94 & & & 0.41 & [12] \\
\hline Ni-SN@C & GCE & $1 \mathrm{M} \mathrm{KOH}$ & & 28 & & & 0.255 & [99] \\
\hline Ni-SN@C & GCE & $\begin{array}{l}1 \mathrm{M} \mathrm{KOH} \\
\text { seawater }\end{array}$ & & 23 & & & 0.255 & [99] \\
\hline $\begin{array}{l}\text { NiCoN }|\mathrm{NixP}| \\
\text { NiCoN }\end{array}$ & NF & seawater & & 165 & & & 1.26 & [100] \\
\hline $\begin{array}{c}\mathrm{Ni}_{5} \mathrm{P}_{4} / \\
\mathrm{Ni}_{2+\delta} \mathrm{O}_{\delta}(\mathrm{OH})_{2-\delta}\end{array}$ & $\mathrm{CC}$ & seawater & & 144 & & & & [101] \\
\hline
\end{tabular}

PBS, phosphate buffer solution; GCE, glass carbon electrode; NF, Ni foam; CC, carbon cloth; NiRuIr_G, graphenesupported NiRuIr; 0.5Rh-G1000, Rh supported by N-doped carbon nanosheets; 0.5Rh-GS1000, Rh supported by N/S-codoped carbon nanosheets; mh-3D MXene, multilevel hollow MXene; BNCNT, boron, nitrogen codoped CNT; C-Co ${ }_{2} \mathrm{P}$, carbon doped $\mathrm{Co}_{2} \mathrm{P}$.

\subsubsection{Noble Metal Alloy Electrocatalysts for HER}

Noble metals (such as Pt and Pd) and their alloys are widely used catalysts for HER due to their high electrical conductivity, excellent stability, and good catalytic activity [102-104]. In the volcano plot, $\mathrm{Pt}$ is located at the top, representing the most promising electrode material superior to other noble metal-based electrocatalysts [105]. However, the high cost inhibits its large-scale application in industry. Alloying Pt with some other transition metals is a good solution to lower the cost. In general, transition metals have three-dimensional orbitals. The alloying process of $\mathrm{Pt}$ changes the outermost electronic states of $\mathrm{Pt}$ atoms, affecting the HER process. For example, alloying the $\mathrm{Pt}$ with $\mathrm{Fe}, \mathrm{Co}, \mathrm{Mo}, \mathrm{Cr}$, and $\mathrm{Ni}$ atoms significantly reduced the overpotential of the catalyst as well as the Tafel slope [25]. In addition, the addition of foreign atoms such as $\mathrm{Fe}, \mathrm{Co}, \mathrm{Mo}, \mathrm{Cr}$, and $\mathrm{Ni}$ effectively mitigated the effect of $\mathrm{Cl}_{2}$ on $\mathrm{Pt}$, thus improving the stability of the catalyst. The Ti/PtMo electrode had the highest catalytic activity and the maintained an initial current density of $91.13 \%$ after $172 \mathrm{~h}$ operation in real seawater. $\mathrm{PtNi}_{\mathrm{x}}$ alloys were also used for catalyzing the HER reaction in seawater splitting [90]. By adjusting the $\mathrm{Pt} / \mathrm{Ni}$ stoichiometric ratio, the final $\mathrm{PtNi}_{5}$ electrode exhibited the best catalytic performance with the minimum starting potential as low as $0.38 \mathrm{~V}$ and a good stability for more than $12 \mathrm{~h}$ operation.

Transition metals have been divided into two groups located at different sides of the Trasatti's volcano plot according to the catalytic properties of HER, i.e., $3 \mathrm{~d}$ series metal atoms (such as $\mathrm{Fe}, \mathrm{Co}$, and $\mathrm{Ni}$ ) on the right side of the volcano plot and metal atoms (such as $\mathrm{Mo}, \mathrm{Cr}$, and $\mathrm{W}$ ) on the left side of the volcano plot with extended d-orbitals [106]. BrewerEngel theory indicates that d-orbital atoms in a half- or full-space state are more conducive 
to the adsorption of $\mathrm{H}$ atoms, and that electrons can be transferred to the $\mathrm{H}_{2} \mathrm{O}$ molecule through the d orbitals to break the O-H bond [107,108]. Therefore, Pt alloying with different transition metals shows different HER performance. For example, the alloy of $\mathrm{Pt}\left(5 \mathrm{~d}^{9} 6 \mathrm{~s}^{1}\right)$ and Mo $\left(4 \mathrm{~d}^{5} 4 \mathrm{~s}^{1}\right)$ showed good HER performance due to adequate adsorption of $\mathrm{H}$ from synergistic interaction; however, the alloy of $\mathrm{Pt}$ and $\mathrm{Cr}\left(3 \mathrm{~d}^{5} 4 \mathrm{~s}^{1}\right)$ showed unsatisfactory performance due to too strong adsorption and thus difficult desorption of $\mathrm{H}$ [26].

In addition to $\mathrm{Pt}$, other noble metals such as $\mathrm{Au}, \mathrm{Ru}$, and Ir have also been investigated for the electrolysis of seawater to produce hydrogen. Zhang et al. [91] prepared NiAu and NiPt alloys on titanium foil at onset potentials of $230 \mathrm{mV}$ and $410 \mathrm{mV}$, respectively, though the NiPt electrode still showed better catalytic activity for HER process. Niu et al. [36] also prepared $\mathrm{RuCo}$ and $\mathrm{RuCoMo}$ alloys by electrodeposition on titanium foil substrates for hydrogen production in seawater catalysis. Ti foil-supported $\mathrm{RuCo}$ and $\mathrm{RuCoMo}$ alloy electrodes required overpotentials of 387 and $550 \mathrm{mV}$, respectively, to achieve a current density of $10 \mathrm{~mA} \mathrm{~cm}^{-2}$.

\subsubsection{Carbon-Supported Noble Metals for HER}

Carbon-supported metal catalysts (CMCs) are receiving increasing attention due to adjustable surface physicochemical properties and simple synthesis process. The use of metal-carbon interaction to modify the surface of metal particles is a good method to improve catalytic activity [109]. Generally, it is necessary to optimize the surface and interface of CMC to make a uniform dispersion of metal loading. Liu et al. successfully synthesized N/S co-doped carbon nanosheet-loaded Rh nanoparticles (Figure 6a,b) [93]. This thin mesoporous nanosheet with a high surface area of $437.1 \mathrm{~m}^{2} / \mathrm{g}$ allowed a uniform dispersion of Rh nanoparticles (Figure $6 \mathrm{c}-\mathrm{f}$ ). The doping of $\mathrm{S}$ into the thin carbon nanosheet enhanced the interaction between Rh nanoparticles and carbon support, promoting electron deviation from $\mathrm{Rh}$ and transfer to the interface of $\mathrm{Rh}$ and carbon. As a result, this Rhbased catalyst exhibited extremely high catalytic activity in seawater at a low loading of only $0.5 \mathrm{wt} \%$, comparable to the performance of commercial $20 \% \mathrm{Pt} / \mathrm{C}$. The catalyst also delivered a current density of $15 \mathrm{~mA} \mathrm{~cm}^{-2}$ for $10 \mathrm{~h}$ with good stability.

(a)
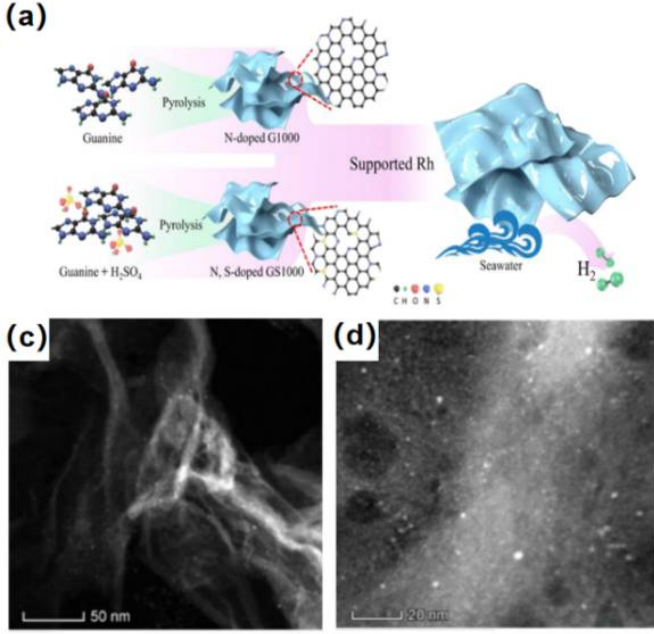

(b)

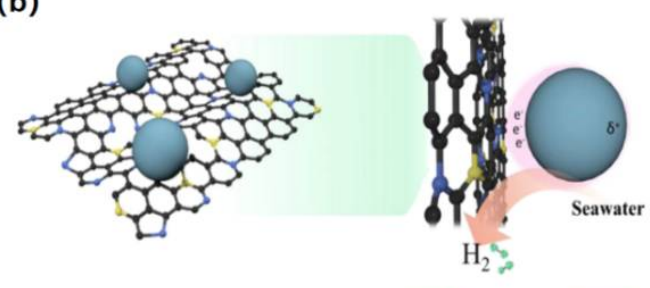

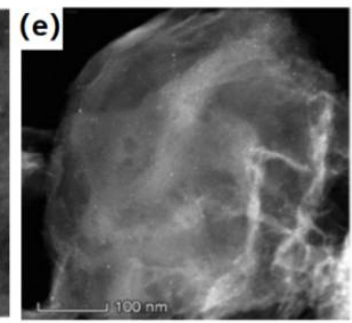

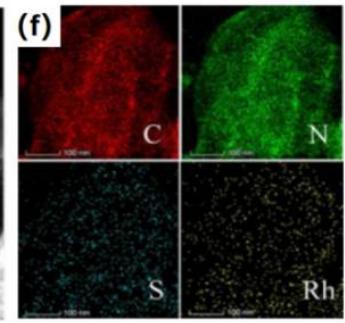

Figure 6. (a) Schematic diagram of the synthesis of Rh-G1000 and Rh-GS1000, (b) schematic diagram between Rh and carbon support, (c-e) HAADF-STEM of 0.5Rh-GS1000, and (f) elemental mapping of 0.5Rh-GS1000. Reproduced with permission from [93]. Copyright (C) 2019, American Chemical Society.

Graphene is a kind of promising carbon-based carrier for catalysts due to its high stability and electron mobility [110]. The use of graphene, as carrier for noble metal catalysts, ensures high catalytic efficiency and improves the stability of noble metals in chloride ionrich electrolytes while reducing the amount of noble metal used. A graphene-loaded nickel, ruthenium, and iridium-based nanostructured catalyst was synthesized by Sarno et al. [92]. 
The iridium element ensured the high hydrogen precipitation activity of this alloy in acidic and seawater environments and enhanced the stability of the alloy. In addition, the different work functions of each metal in the alloy promoted the aggregation of electrons on the Ir surface, which further enhanced the activity. Moreover, the negative charges accumulated on Ir prevented the attack of chloride anions. The highly conductive graphene network stabilized the nanoparticles immobilized on it and reduced the charge transfer resistance at the electrode. In $0.5 \mathrm{M} \mathrm{H}_{2} \mathrm{SO}_{4}$, an overpotential of $0.06 \mathrm{~V}$ and a Tafel slope of $28 \mathrm{mV} \mathrm{dec}^{-1}$ were maintained even after 11,000 cycles. The samples had a Tafel slope of $48 \mathrm{mVdec}^{-1}$ and maintained a low overpotential of $0.08 \mathrm{~V}$ with no significant loss in current density after 250 cycles in real seawater. The results showed that the synthesized electrocatalysts were efficient for HER performance in real seawater, benefiting from the presence of graphene carriers and synergistic alloying effects.

\subsubsection{MXene-Based Complexes for HER}

MXene is a novel two-dimensional material that can be expressed as $M_{n+1} X_{n} T_{x}$ $(n=1-3)$, with $\mathrm{M}$ denoting early transition metals (e.g., Ti, Mo, Nb, Ta, and V), X denoting $\mathrm{N}$ or $\mathrm{C}$, and $\mathrm{T}$ representing surface groups [111]. MXene is promising as catalyst because of its structural diversity, high hydrophilicity, mechanical stability, and high electrical conductivity [112-114]. To maximize the exploitation of MXene for catalytic applications, it is often possible to design it as a three-dimensional hollow structure. Three-dimensional hollow structures can largely expose active surface area and prevent MXene aggregation to some extent. For example, a multi-stage hollow MXene improved Pt utilization by binding to ultra-low levels of Pt and enhanced charge transfer rates, intermediate $\mathrm{H}$ binding, and ion exchange rates [94]. When it was applied directly to the electrolysis of natural seawater, the catalyst showed significant catalytic activity and durability, far exceeding that of commercial 20\% Pt/C. Wang et al. [27] also successfully prepared a novel electrocatalytic material $\mathrm{VS}_{2} @ \mathrm{~V}_{2} \mathrm{C}$, in which $\mathrm{T}-\mathrm{VS}_{2}$ was vertically embedded on a layered $\mathrm{V}_{2} \mathrm{C}$ substrate. $\mathrm{VS}_{2} @ \mathrm{~V}_{2} \mathrm{C}$ showed good catalytic performance in seawater at current densities greater than $100 \mathrm{~mA} \mathrm{~cm}^{-2}$. The $\mathrm{VS}_{2} @ \mathrm{~V}_{2} \mathrm{C}$ possessed a high carrier mobility and a low free energy for hydrogen adsorption, in which the $\mathrm{VS}_{2}$ nanosheets provided support and the $\mathrm{S}$ sites at their edges helped to facilitate $\mathrm{H}$ adsorption and release. In addition, Miao et al. prepared a composite containing h-MoN NPs and B, N co-doped carbon nanotubes (h-MoN@BNCNT) [95]. The h-MoN NPs were encapsulated in B, N co-doped carbon nanotubes, which facilitated the prevention of aggregation and poisoning of h-MoN NPs. The synergistic effects on the B and N doped CNTs and h-MoN NPs generated HER active sites. In seawater electrolytes, h-MoN@BNCNT exhibited a larger current density and remarkable stability, even better than the commercial $\mathrm{Pt} / \mathrm{C}$.

\subsubsection{Metal Phosphides for HER}

The electronegative $\mathrm{P}$ atom in the metal phosphides can capture the positively charged protons, and at the same time, it provides a higher activity for HER. With an appropriate ratio of metal to phosphorus atoms, the metal phosphide can exhibit excellent electrical conductivity. CoMoP@C (Figure 7a-d) showed good catalytic activity close to 20\% Pt/C at $\mathrm{pH}=0-1$ and better than $20 \% \mathrm{Pt} / \mathrm{C}$ at high overpotential at $\mathrm{pH}=2-14$ [115]. The strong proton absorption capacity of the carbon shell effectively contributed to the HER performance. Meanwhile, the carbon shell on the CoMoP core protected the catalyst from corrosion, agglomeration, and poisoning in seawater. As a result, CoMoP@C exhibited outstanding HER performance in real seawater. Lv et al. prepared porous feather-like NiCoP electrocatalysts on foam nickel by hydrothermal and phosphorylation methods (Figure 7e) [96]. Meanwhile, their porous structure and conductive substrate were beneficial to increase the specific surface area and expose more active sites (Figure $7 \mathrm{f}-\mathrm{h}$ ), which also facilitated the release of the generated $\mathrm{H}_{2}$. In addition, the synergistic contribution of the $3 \mathrm{D}$ pore structures, electronic effects, and conductive substrates greatly improved the 
electrochemical stability. $\mathrm{NiCoP} / \mathrm{NF}$ exhibited excellent activity and stability in seawater at a current density of $10 \mathrm{~mA} \mathrm{~cm}^{-2}$ and an overpotential of $287 \mathrm{mV}$.
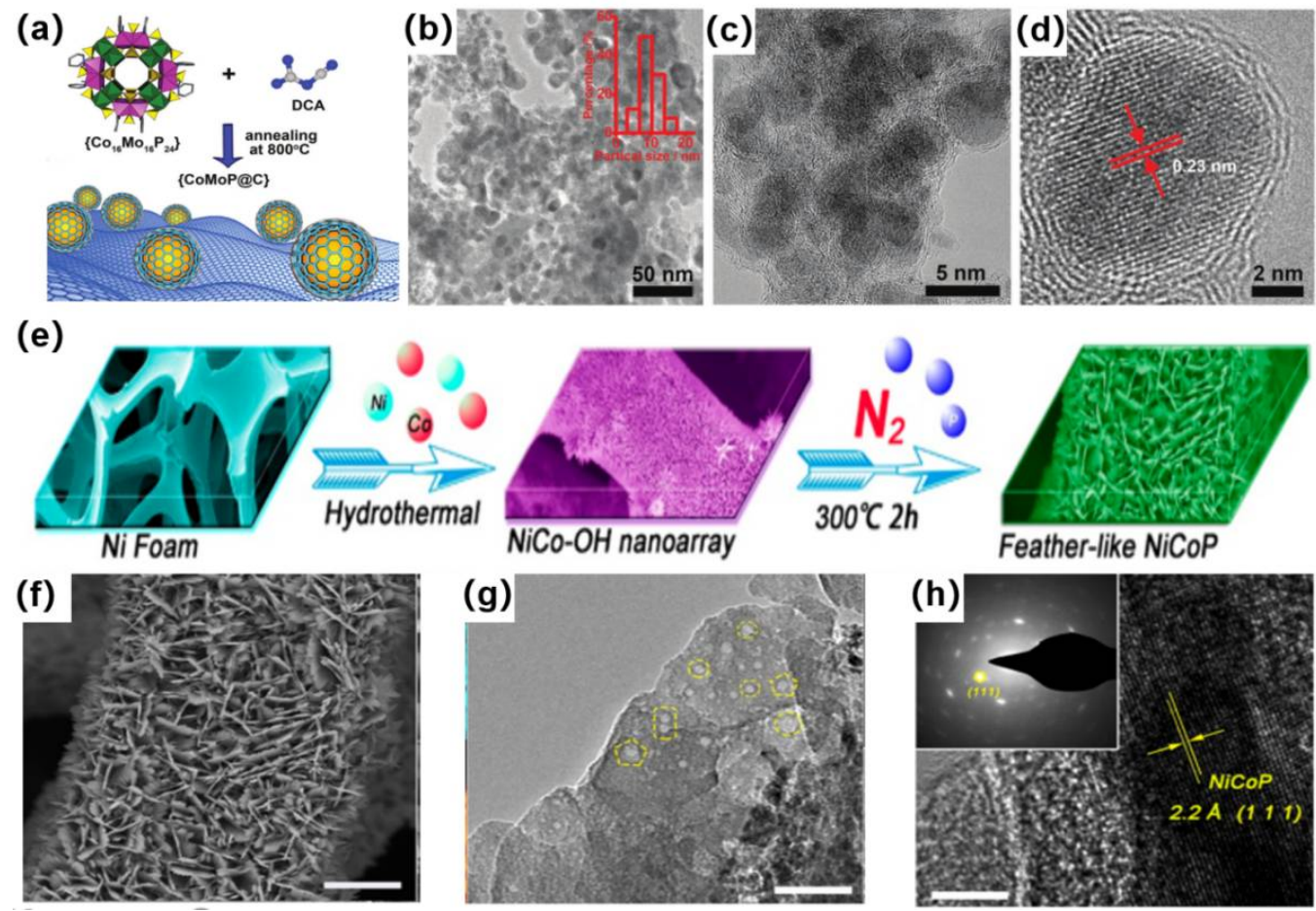

Figure 7. (a) Schematic diagram of the synthesis of CoMoP@C, (b) TEM images of CoMoP@C, and (c,d) HRTEM images of CoMoP@C. Reproduced with permission from [115]. Copyright (C 2017 Royal Society of Chemistry, (e) Synthesis of NiCoP and schematic diagram of its structure, (f) SEM images of the $\mathrm{NiCoP}$, (g) TEM images, and (h) HRTEM image and SAED pattern (inset) of the NiCoP. Reproduced with permission from [96]. Copyright (C) 2019, ACS Appl. Energy Mater.

Recently, Tian et al. used Ni-Co-P as the core and a hybrid polymer of pyrrole and sodium polyphenylene sulfonate as the shell to make an ordered growth of core/shell type PSS-PPy/Ni-Co-P HER electrocatalyst on copper foil [97]. The electrical conductivity and hydrophilicity as well as electronic structure of the Ni-Co-P were optimized by the PSS-PPy. Another carbon-doped nanoporous cobalt phosphide $\mathrm{C}-\mathrm{Co}_{2} \mathrm{P}$ (Figure $8 \mathrm{a}-\mathrm{d}$ ) also exhibited excellent catalytic activity in an artificial alkaline seawater electrolyte with a mixture of $\mathrm{NaCl}, \mathrm{MgCl}_{2}$, and $\mathrm{CaCl}_{2}$ chlorides (Figure 8e) [28]. Carbon atoms with strong electronegativity and small atomic radius adjusted the electronic structure of $\mathrm{Co}_{2} \mathrm{P}$ and weakened the $\mathrm{Co}-\mathrm{H}$ bond, finally promoting HER kinetics. In addition, $\mathrm{C}$ doping introduced two-step $\mathrm{H}$-transfer pathways through the formation of $\mathrm{C}-\mathrm{H}_{\mathrm{ad}}$ intermediates, which lowered the energy barrier for hydrolysis (Figure 8f). 

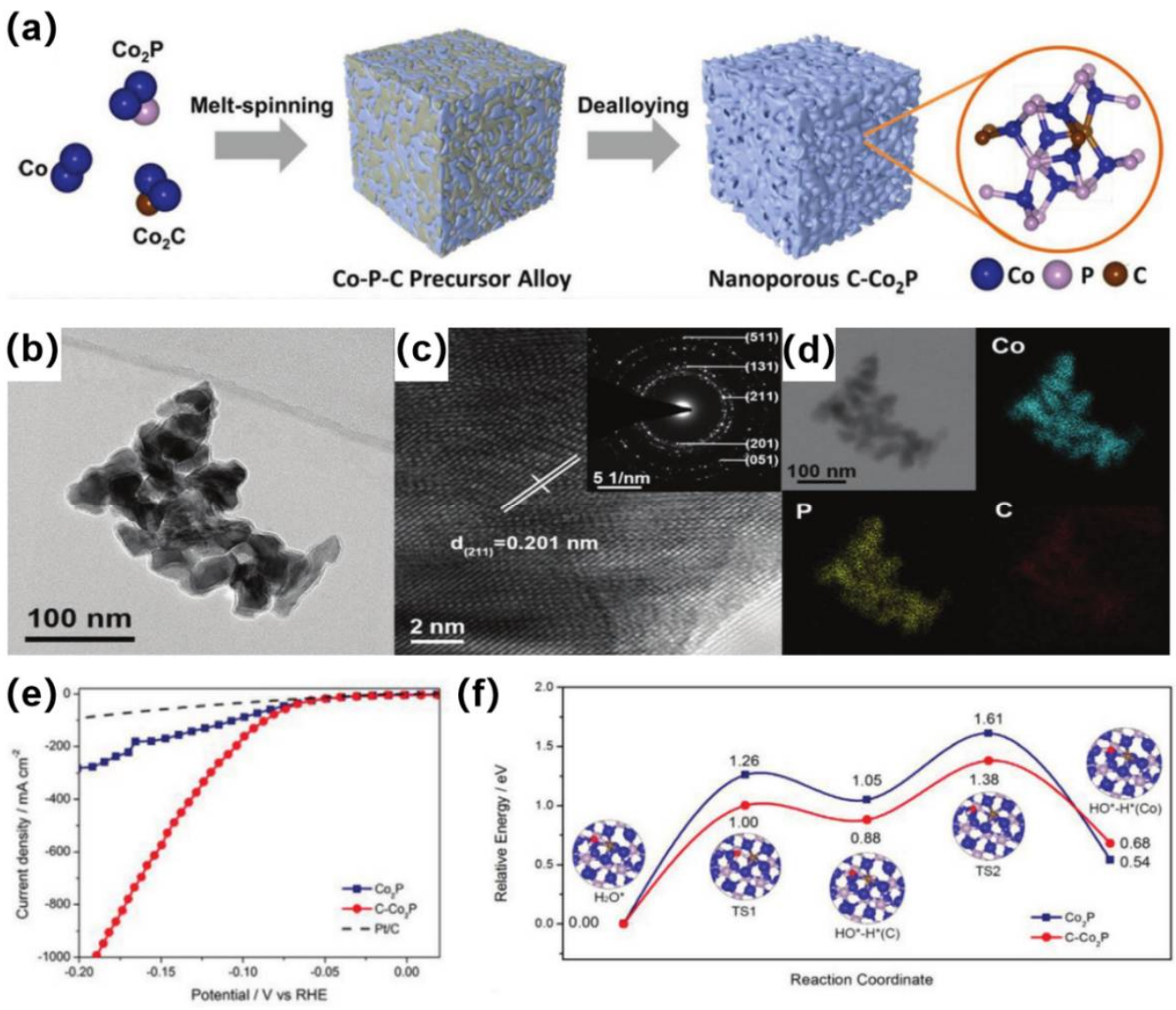

Figure 8. (a) Schematic of the preparation of nanoporous $\mathrm{C}-\mathrm{Co}_{2} \mathrm{P}$ electrocatalysts, (b) TEM image, (c) HRTEM image, (d) the element distribution of nanoporous $\mathrm{C}-\mathrm{Co}_{2} \mathrm{P},(\mathbf{e})$ Polarization curves of the as-prepared catalysts in simulated alkaline seawater, and (f) The relative energy diagram along the proton-deliver pathway on $\mathrm{Co}_{2} \mathrm{P}$ and $\mathrm{C}-\mathrm{Co}_{2} \mathrm{P}$ surfaces. Reproduced with permission from [28]. Copyright (C) 2021, Wiley-VCH GmbH.

\subsubsection{Metal Oxides and Hydroxides for HER}

Metal oxides are considered as an effective HER catalyst because of their diverse crystal structures, great abundance, and high catalytic activity, which can show Pt-like performance in natural seawater. However, there is still a long way for the industrialization of metal oxides as catalysts for HER. Mn-doped nickle oxide/Ni (Mn-NiO/Ni) was prepared by pyrolyzing $\mathrm{Mn}-\mathrm{MOF} / \mathrm{Ni}-\mathrm{F}$ precursor in an inert environment, in which nickle foam served as a substrate and provided nickel elements to interact with Mn-MOF [89]. Amal et al. used a simple and controllable method to design carbon-based $\mathrm{NiO} / \mathrm{Ni}$ for HER and found that the degree of oxidation of Ni had a great impact on performance [116]. Doping noble metal atoms in metal oxides can tune the electronic structure of the catalyst, where $\mathrm{Ru}$ was more cost-effective than other noble metals. Since the binding energy of $\mathrm{Rh}$ to hydrogen is similar to that of $\mathrm{Pt}$, it is potentially advantageous and promising for HER electrocatalysis. In addition, the structure of the metal oxide materials also plays a moderating role on the electrocatalytic performance. The arrangement of atoms in amorphous materials can provide a large number of exposed surfaces and defects [117]. An ultra-low $\mathrm{Ru}$ amorphous cobalt-based oxide $\mathrm{Ru}-\mathrm{CoO}_{\mathrm{x}} / \mathrm{NF}$ (Figure 9a) was constructed by Wu et al. [98]. The amorphous structure provided more active sites for electrocatalytic reactions. In addition, the incorporation of $\mathrm{Ru}$ elements promoted internal charge transfer, resulting in better performance (Figure $9 b-d$ ). These positive factors effectively drove its electrolysis under high current density conditions in seawater media (Figure 9e,f). 

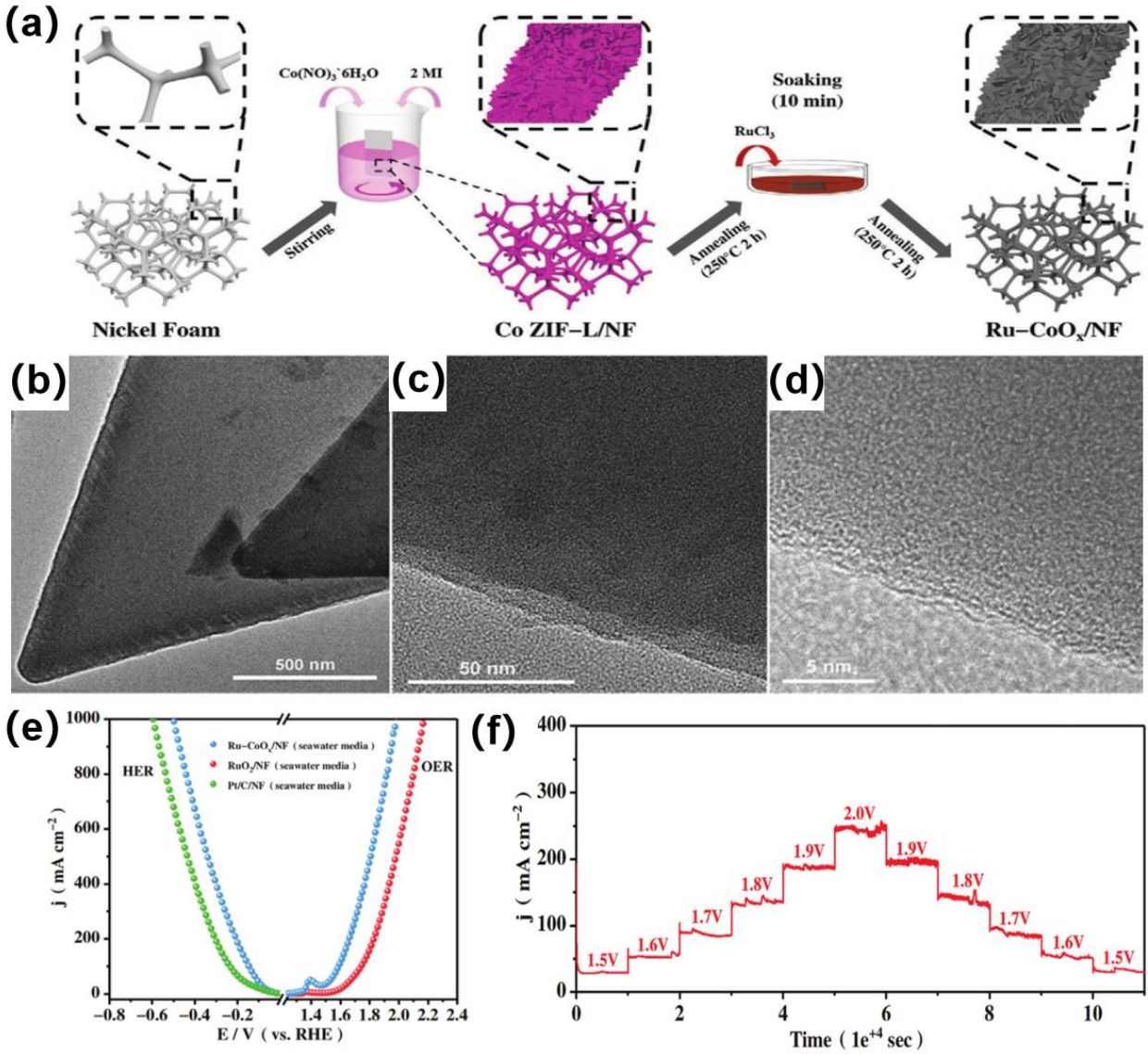

Figure 9. (a) Schematic representation of the synthesis of Ru-CoOx/NF, (b-d) TEM images of Ru$\mathrm{CoO}_{\mathrm{x}} / \mathrm{NF}$, (e) polarization curves of $\mathrm{Ru}-\mathrm{CoO}_{\mathrm{x}} / \mathrm{NF}$ in seawater, and (f) multipotential stability test chart of $\mathrm{Ru}-\mathrm{CoO}_{x} / \mathrm{NF}$ in seawater media. Reproduced with permission from [98]. Copyright (C) 2021, Wiley-VCH GmbH.

In addition to metal oxides, metal hydroxides have also been applied in HER. For example, Jiang et al. [118] synthesized NiFe-LDH/FeOOH heterostructure nanosheets on the surface of NF by electrodeposition. Due to the interaction between FeOOH and NiFe-LDH, the catalyst achieved significant HER performance in $1.0 \mathrm{M} \mathrm{KOH}+0.5 \mathrm{M} \mathrm{NaCl}$ electrolyte. When the current density was $10 \mathrm{~mA} \mathrm{~cm} \mathrm{~cm}^{-2}$ and $100 \mathrm{~mA} \mathrm{~cm}^{-2}$, the overpotential of NiFe-LDH/FeOOH was 181.8 and $286.2 \mathrm{mV}$, respectively. The $\mathrm{NiFe}-\mathrm{LDH} / \mathrm{FeOOH}$ showed significant catalytic activity with good stability for $105 \mathrm{~h}$ operation at a current density of $100 \mathrm{~mA} \mathrm{~cm}{ }^{-2}$. In addition, it was found that the cation doping can regulate the three-dimensional energy level of electrocatalysts or adjust the electronic structure and the surface adsorption energy of intermediates [119,120]. $\mathrm{Zr}$ is one of the most abundant elements on earth and has a variety of valence states. Adding $\mathrm{Zr}^{4+}$ ions in a stable oxidation state into the catalyst cannot only adjust the electronic structure but also reduce the crystallinity and expand the active surface area [74,121]. Liu et al. [74] studied HER performance of the $\mathrm{Zr}$ doped low crystalline layered double hydroxides on the surface of nickel foam, which showed $20 \mathrm{~h}$ stable operation in a water-splitting electrolyzer in $1 \mathrm{M} \mathrm{KOH}+0.5 \mathrm{M} \mathrm{NaCl}$ electrolyte.

\subsubsection{Metal Nitrides for HER}

Metal nitrides showed great potential in seawater electrolysis due to their high conductivity and excellent corrosion resistance [12,18,119]. In general, alloying, vacancy engineering, heteroelement doping, and interface engineering can be used to further improve the catalytic efficiency of metal nitrides, so as to make up for the inherent defects of metal nitrides [122-126]. Jin et al. applied a transition metal-catalyzed phase transition approach in combination with a two-dimensional lateral growth method to synthesize atomic-scale $\mathrm{Mo}_{5} \mathrm{~N}_{6}$ nanosheets 
(Figure 10a-c) [12]. Compared with the traditional nitrogen-deficient metal nitrides, the twodimensional $\mathrm{Mo}_{5} \mathrm{~N}_{6}$ nanosheets prepared by rich metal-nitrogen bonds showed excellent HER performance in natural seawater (Figure 10d) and stability under high current for $100 \mathrm{~h}$. The performance was far better than the $\mathrm{Pt} / \mathrm{C}$ benchmark and other metal nitrides counterparts. The high activity of $\mathrm{Mo}_{5} \mathrm{~N}_{6}$ stemmed from its Pt-like electronic structure. Its stability came from the high valence of its Mo atoms, which made it relatively less susceptible to active-site poisoning by other ions in seawater. In addition, the electronic structure of metal nitrides can be tuned by adjusting the ratio of nitrogen atoms in the metal matrix $[77,121,125]$. The nitrogen content in metal nitrides was controlled by nitrogen enrichment process and incomplete nitridation process $[127,128]$. The purpose of the nitrogen enrichment process was to embed additional nitrogen atoms in the metal nitrides lattice, but this process is often only possible under a high temperature and high pressure environment $[127,129]$. The incomplete nitridation process can promote the formation of the metal/metal nitridation interface, which usually has better electrical conductivity and electrocatalytic performance $[99,130]$. Jin et al. used an unsaturated nitridation process to synthesize a nickel surface nitride wrapped in a carbon shell (Ni-SN@C) [99]. Compared with conventional transition metal nitrides or metal/metal nitride heterostructures, Ni-SN@C possessed no detectable bulk nickel nitride phase with unsaturated NiN bonds on the surface. Instead, Ni-SN@C possessed metallic nickel as its main chemical component with a unique unsaturated surface $\mathrm{NiN}$ bond. At a current density of $10 \mathrm{~mA} \mathrm{~cm}^{-2}$, the overpotential of the Ni-SN@C catalyst was as low as $23 \mathrm{mV}$ in alkaline seawater. This strategy not only produced catalysts with desirable characteristics of metal nitrides but also promoted the redistribution of charges on the surface of the catalyst, making it excellently corrosion resistant and highly active for HER in seawater electrolysis.
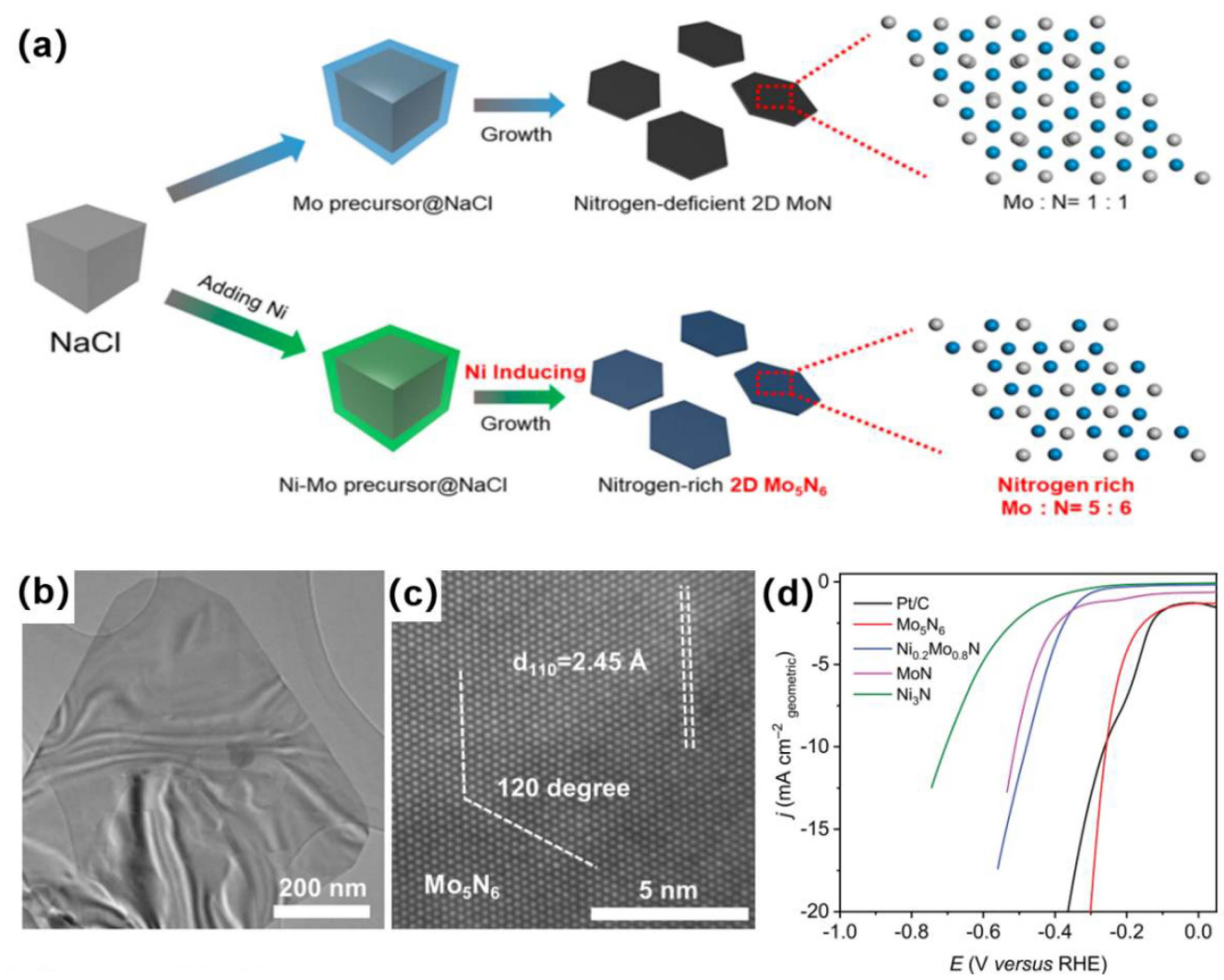

Figure 10. (a) Schematic diagram of the synthesis of $\mathrm{MoN}$ and $\mathrm{Mo}_{5} \mathrm{~N}_{6}$ nanosheets, (b) low-resolution TEM image, (c) high-resolution STEM image of $\mathrm{Mo}_{5} \mathrm{~N}_{6}$, and (d) LSV curves of different types of catalysts measured in Ar-saturated natural seawater. Reproduced with permission from [12]. Copyright (c) 2018, American Chemical Society. 


\subsubsection{Hybrid Electrocatalysts for HER}

Thus far, metal oxides, hydroxides, nitrides, phosphides, etc., have proven to be effective catalysts for hydrogen production in seawater electrolytes. In addition, the heterogeneous structures formed by a combination of them have the same high catalytic activity. The hybridization of electrocatalysts can induce synergistic hybrid catalyst systems by the presence of strong electronic interactions between two compounds, changing the charge distribution inside the hybrid electrocatalyst and optimizing the adsorption energy of $\mathrm{H}[86,87]$. Yu et al. prepared a sandwich-like nickel phosphide $\left(\mathrm{Ni}_{\mathrm{x}} \mathrm{P}\right)$ microplate array by decorating the sides of nickel cobalt nitride ( $\mathrm{NiCoN})$ nanoparticles with nanostructured HER catalysts [100]. The sandwichlike catalyst $\left(\mathrm{NiCoN} / \mathrm{Ni}_{x} \mathrm{P} \mid \mathrm{NiCoN}\right)$ had a high specific surface area, which enhanced the catalytic activity of each active site and provided high conductivity for efficient charge transfer. NiCoN I NixP I NiCoN in a natural seawater electrolyte only required an overpotential of $165 \mathrm{mV}$ to achieve a current density of $10 \mathrm{~mA} \mathrm{~cm}^{-2}$, while its stability was impressive due to the good chloride resistance of the internal $\mathrm{Ni}_{x} \mathrm{P}$ microplate array. In addition, Huang et al. developed a hybrid electrocatalyst consisting of a hydrogen acceptor $\mathrm{Ni}_{5} \mathrm{P}_{4}$ and a hydroxyl acceptor amorphous nickel hydrogen (oxygen) oxide $\left[\mathrm{Ni}_{2+\delta} \mathrm{O}_{\delta}(\mathrm{OH})_{2-\delta}\right]$ to promote HER activity by a simple treatment of the nickel precursor in a nitrogen atmosphere [101]. The $\mathrm{Ni}_{5} \mathrm{P}_{4}$ and $\mathrm{Ni}_{2+\delta} \mathrm{O}_{\delta}(\mathrm{OH})_{2-\delta}$ hybridization provided protection to enhance the electrocatalytic performance and specific surface area of the composite electrocatalyst, and at the same time generated good electronic interaction and synergistic inhibition of $\mathrm{P}-\mathrm{H}_{\mathrm{ads}}$ bonds to favor the water adsorption, optimize hydrogen adsorption free energy, and trigger the catalytic pathway in all $\mathrm{pH}$ ranges. The prepared hybrid catalysts exhibited an overpotential of $144 \mathrm{mV}$ at a current density of $10 \mathrm{~mA} \mathrm{~cm}^{-2}$ and $108 \mathrm{mV} \mathrm{dec}^{-1}$ in real seawater. The excellent performance was ascribed to the higher specific surface area, the synergistic effect between the phosphide, and the hydroxide and the electronic interaction.

In general, compared with OER, HER faces few competitive reactions. However, impurities in seawater cause negative effects during the HER reaction process, such as the insoluble precipitation. At this stage, $\mathrm{Pt}$ and other noble metals are still the most outstanding catalysts for HER, but the high cost of Pt limits its wide application. Up to now, various noble metal alloys and transition metal compounds have been successfully studied for HER in seawater electrolysis [25,90]. Alloying Pt with other transition metals, such as $\mathrm{PtM}(\mathrm{M}=\mathrm{Cr}, \mathrm{Fe}, \mathrm{Co}, \mathrm{Ni}, \mathrm{Mo})$, can effectively reduce the amount of noble metals while maintaining the catalytic activity of pure $\mathrm{Pt}[25,90]$. In addition, carbon supported catalysts cannot only have a better dispersion of the noble metals but also improve the stability in seawater [93]. In addition to the above noble metals, many other non-noble materials, such as metal phosphides, nitrides, oxides (hydroxides), and new two-dimensional materials MXenes, also have significant HER performance and good resistance to impurities in seawater, which are promising catalysts in seawater electrolysis [74,98].

\section{Conclusions and Outlook}

Seawater is an inexhaustible resource on the planet; thus, the hydrogen production through the electrolysis of seawater can be effective in alleviating the energy crisis to some extent. Despite many efforts devoted into the field of seawater electrolysis in recent years, there is large space for the improvement of seawater electrolysis for high-performance production of hydrogen. Obviously, seawater electrolysis is more complex than freshwater electrolysis due to the presence of multiple cations and anions. Herein, we review the recent progress and summarize in detail the current status of research on HER and OER catalysts for seawater electrolysis, from fundamental mechanisms to the performance of catalysts.

Extensive research has been carried out on various materials, such as metal oxides (hydroxides), metal nitrides, metal phosphides, metal borides, noble metal alloy catalysts, and so on, for seawater electrolysis. Still, the catalytic activity and stability of most of the reported catalysts are not satisfactory to meet the requirement for practical application. As can be found from Tables 1 and 2, the overpotential of these catalysts is not low enough. Furthermore, most of the electrolytes for current research are artificial saline water rather than real seawater, which 
increases the complexity of seawater electrolysis for hydrogen production. Therefore, in order to achieve high-performance seawater electrolysis, we believe more efforts are needed in the following directions:

(1) Combining experimental and theoretical analyses to further confirm the reaction pathways and active sites of catalysts for HER and OER in seawater electrolysis: in addition to monometallic compounds, various polymetallic compounds and heterostructured catalysts have been extensively investigated as catalysts in seawater electrolysis. It is a trend to design catalysts composed of more than a single metal component by taking advantage of the synergistic effect of multimetal components. As catalyst components become more complex, it is more difficult to identify the electrocatalytic reaction pathways as well as the active sites. Therefore, systematic research based on theoretical analyses is necessary, which can provide guidance for designing materials with desirable structures and properties.

(2) Employing in situ characterization methods to unravel the true active sites of catalysts: many current electrocatalysts, such as metal oxides, phosphides, and nitrides, undergo surface oxidation or reconstitution during seawater electrolysis, which means that the true active sites of the catalyst may be altered during the reaction. As each step in the catalytic reaction process changes rapidly, we need in situ characterization techniques to track changes in the intermediates during the catalytic reaction process. It will provide clear principle and guidance to design high-efficiency catalysts if more in situ techniques such as in situ XAS, Raman, Fourier transform infrared spectroscopy, and other novel techniques are involved for the mechanistic studies.

(3) Exploring and developing electrocatalysts with high activity and stability in seawater: Not only multiple cations but also chloride anions in seawater interfere with the water splitting reactions. It is highly desirable to synthesize catalysts with higher selectivity to HER and OER than other competitive reactions. To obtain highly efficient electrocatalysts for seawater electrolysis, modulating the electronic structure of active sites is of great significance and plays a major role in the improvement of catalytic performance. To optimize the electronic structure of catalysts, alloying, vacancy engineering, heteroelement doping, and interface engineering are common methods. Integration of different active materials into a hybrid catalyst is also a good solution for developing high-performance catalysts.

(4) Designing advanced reactors specific for seawater electrolysis: The current research of seawater electrolysis for hydrogen production is mostly focused on the catalysts. To realize the electrocatalytic production of hydrogen, we need to consider the entire reactor rather than the catalysts only. It is necessary to reasonably design reactors which are adaptable to specific seawater electrolysis. For example, the design of asymmetric reactors is considered to be more promising [31,88], which consists of alkaline water in the anode chamber and seawater in the cathode chamber. Such design not only facilitates the diffusion of $\mathrm{Cl}^{-}$to the anode but also protects the anode catalyst, which is of significance in seawater electrolysis.

Author Contributions: Resources, W.L.; writing—original draft preparation, S.J.; writing—review and editing, T.Z., C.L., Y.W. and Q.Z.; supervision, H.S., Q.Z. and W.L.; project administration, H.S. and Q.Z.; funding acquisition, H.S. and Q.Z. All authors have read and agreed to the published version of the manuscript.

Funding: Q.Z. thanks the the Research Grants Council of the Hong Kong Special Administrative Region (PDFS2021-4S12). This work is financially supported by the National Natural Science Foundation of China (51571002) and the Beijing Municipal Natural Science Foundation (2212025).

Conflicts of Interest: The authors declare no conflict of interest. 


\section{References}

1. Chu, S.; Cui, Y.; Liu, N. The path towards sustainable energy. Nat. Mater. 2017, 16, 16-22. [CrossRef]

2. Jacobson, M.Z.; Colella, W.; Golden, D. Cleaning the air and improving health with hydrogen fuel-cell vehicles. Science 2005, 308, 1901-1905. [CrossRef]

3. Fukuzumi, S.; Lee, Y.M.; Nam, W. Fuel production from seawater and fuel cells using seawater. ChemSusChem 2017, 10, 4264-4276. [CrossRef]

4. Kumaravel, V.; Abdel-Wahab, A. A short review on hydrogen, biofuel, and electricity production using seawater as a medium. Energy Fuels 2018, 32, 6423-6437. [CrossRef]

5. Zhang, J.; Hu, W.; Cao, S.; Piao, L. Recent progress for hydrogen production by photocatalytic natural or simulated seawater splitting. Nano Res. 2020, 13, 2313-2322. [CrossRef]

6. Tian, L.; Zhai, X.; Wang, X.; Pang, X.; Li, J.; Li, Z. Morphology and phase transformation of $\alpha-\mathrm{MnO}_{2} / \mathrm{MnOOH}$ modulated by N-CDs for efficient electrocatalytic oxygen evolution reaction in alkaline medium. Electrochim. Acta 2020, 337, 135823. [CrossRef]

7. Li, Z.; Song, M.; Zhu, W.; Zhuang, W.; Du, X.; Tian, L. MOF-derived hollow heterostructures for advanced electrocatalysis. Coord. Chem. Rev. 2021, 439, 213946. [CrossRef]

8. Xu, S.; Zhao, H.; Li, T.; Liang, J.; Lu, S.; Chen, G.; Gao, S.; Asiri, A.M.; Wu, Q.; Sun, X. Iron-based phosphides as electrocatalysts for the hydrogen evolution reaction: Recent advances and future prospects. J. Mater. Chem. A 2020, 8, 19729-19745. [CrossRef]

9. Dresp, S.R.; Dionigi, F.; Klingenhof, M.; Strasser, P. Direct electrolytic splitting of seawater: Opportunities and challenges. ACS Energy Lett. 2019, 4, 933-942. [CrossRef]

10. Tong, W.; Forster, M.; Dionigi, F.; Dresp, S.; Erami, R.S.; Strasser, P.; Cowan, A.J.; Farràs, P. Electrolysis of low-grade and saline surface water. Nat. Energy 2020, 5, 367-377. [CrossRef]

11. Cheng, F.; Feng, X.; Chen, X.; Lin, W.; Rong, J.; Yang, W. Synergistic action of Co-Fe layered double hydroxide electrocatalyst and multiple ions of sea salt for efficient seawater oxidation at near-neutral pH. Electrochim. Acta 2017, 251, 336-343. [CrossRef]

12. Jin, H.; Liu, X.; Vasileff, A.; Jiao, Y.; Zhao, Y.; Zheng, Y.; Qiao, S.-Z. Single-crystal nitrogen-rich two-dimensional Mo ${ }_{5} \mathrm{~N}_{6}$ nanosheets for efficient and stable seawater splitting. ACS Nano 2018, 12, 12761-12769. [CrossRef] [PubMed]

13. Ge, R.; Wang, S.; Su, J.; Dong, Y.; Lin, Y.; Zhang, Q.; Chen, L. Phase-selective synthesis of self-supported RuP films for efficient hydrogen evolution electrocatalysis in alkaline media. Nanoscale 2018, 10, 13930-13935. [CrossRef]

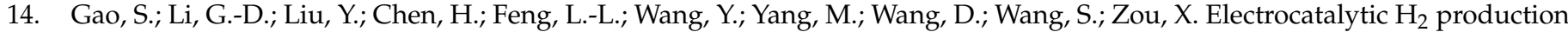
from seawater over Co, N-codoped nanocarbons. Nanoscale 2015, 7, 2306-2316. [CrossRef] [PubMed]

15. Zhao, Q.; Wang, Y.; Lai, W.-H.; Xiao, F.; Lyu, Y.; Liao, C.; Shao, M. Approaching a high-rate and sustainable production of hydrogen peroxide: Oxygen reduction on Co-N-C single-atom electrocatalysts in simulated seawater. Energy Environ. Sci. 2021, 14, 5444-5456. [CrossRef]

16. Kuang, Y.; Kenney, M.J.; Meng, Y.; Hung, W.-H.; Liu, Y.; Huang, J.E.; Prasanna, R.; Li, P.; Li, Y.; Wang, L. Solar-driven, highly sustained splitting of seawater into hydrogen and oxygen fuels. Proc. Natl. Acad. Sci. USA 2019, 116, 6624-6629. [CrossRef]

17. Van de Krol, R.; Grätzel, M. Photoelectrochemical Hydrogen Production; Springer: New York, NY, USA, $2012 ;$ Volume 90.

18. Yu, L.; Zhu, Q.; Song, S.; McElhenny, B.; Wang, D.; Wu, C.; Qin, Z.; Bao, J.; Yu, Y.; Chen, S. Non-noble metal-nitride based electrocatalysts for high-performance alkaline seawater electrolysis. Nat. Commun. 2019, 10, 1-10. [CrossRef]

19. Yu, L.; Wu, L.; McElhenny, B.; Song, S.; Luo, D.; Zhang, F.; Yu, Y.; Chen, S.; Ren, Z. Ultrafast room-temperature synthesis of porous S-doped Ni/Fe (oxy)hydroxide electrodes for oxygen evolution catalysis in seawater splitting. Energy Environ. Sci. 2020, 13, 3439-3446. [CrossRef]

20. Wu, X.; Yang, Y.; Zhang, T.; Wang, B.; Xu, H.; Yan, X.; Tang, Y. $\mathrm{CeO}_{\mathrm{x}}$-decorated hierarchical $\mathrm{NiCo}_{2} \mathrm{~S}_{4}$ hollow nanotubes arrays for enhanced oxygen evolution reaction electrocatalysis. ACS Appl. Mater. Interfaces 2019, 11, 39841-39847. [CrossRef] [PubMed]

21. El-Moneim, A.A.; Kumagai, N.; Hashimoto, K. Mn-Mo-W oxide anodes for oxygen evolution in seawater electrolysis for hydrogen production. Mater. Trans. 2009, 50, 1969-1977. [CrossRef]

22. Vos, J.G.; Wezendonk, T.A.; Jeremiasse, A.W.; Koper, M.T. $\mathrm{MnO}_{\mathrm{x}} / \mathrm{IrO}_{\mathrm{x}}$ as selective oxygen evolution electrocatalyst in acidic chloride solution. J. Am. Chem. Soc. 2018, 140, 10270-10281. [CrossRef] [PubMed]

23. Gupta, S.; Forster, M.; Yadav, A.; Cowan, A.J.; Patel, N.; Patel, M. Highly efficient and selective metal oxy-boride electrocatalysts for oxygen evolution from alkali and saline solutions. ACS Appl. Energy Mater. 2020, 3, 7619-7628. [CrossRef]

24. Wu, L.; Yu, L.; McElhenny, B.; Xing, X.; Luo, D.; Zhang, F.; Bao, J.; Chen, S.; Ren, Z. Rational design of core-shell-structured CoP,@ FeOOH for efficient seawater electrolysis. Appl. Catal. B Environ. 2021, 294, 120256. [CrossRef]

25. Li, H.; Tang, Q.; He, B.; Yang, P. Robust electrocatalysts from an alloyed Pt-Ru-M (M = Cr, Fe, Co, Ni, Mo)-decorated Ti mesh for hydrogen evolution by seawater splitting. J. Mater. Chem. A 2016, 4, 6513-6520. [CrossRef]

26. Zheng, J.; Zhao, Y.; Xi, H.; Li, C. Seawater splitting for hydrogen evolution by robust electrocatalysts from secondary $\mathrm{M}(\mathrm{M}=\mathrm{Cr}$, $\mathrm{Fe}, \mathrm{Co}, \mathrm{Ni}, \mathrm{Mo}$ ) incorporated Pt. RSC Adv. 2018, 8, 9423-9429. [CrossRef]

27. Wang, Z.; Xu, W.; Yu, K.; Feng, Y.; Zhu, Z. 2D heterogeneous vanadium compound interfacial modulation enhanced synergistic catalytic hydrogen evolution for full $\mathrm{pH}$ range seawater splitting. Nanoscale 2020, 12, 6176-6187. [CrossRef]

28. Xu, W.; Fan, G.; Zhu, S.; Liang, Y.; Cui, Z.; Li, Z.; Jiang, H.; Wu, S.; Cheng, F. Electronic structure modulation of nanoporous cobalt phosphide by carbon doping for alkaline hydrogen evolution reaction. Adv. Funct. Mater. 2021, 46, 2107333. [CrossRef]

29. Wang, C.; Shang, H.; Jin, L.; Xu, H.; Du, Y. Advances in hydrogen production from electrocatalytic seawater splitting. Nanoscale 2021, 13, 7897-7912. [CrossRef] 
30. Yao, Y.; Gao, X.; Meng, X. Recent advances on electrocatalytic and photocatalytic seawater splitting for hydrogen evolution. Int. J. Hydrogen Energy 2021, 46, 9087-9100. [CrossRef]

31. Khatun, S.; Hirani, H.; Roy, P. Seawater electrocatalysis: Activity and selectivity. J. Mater. Chem. A 2021, 9, 74-86. [CrossRef]

32. Bolar, S.; Shit, S.; Murmu, N.C.; Kuila, T. Progress in theoretical and experimental investigation on seawater electrolysis: Opportunities and challenges. Sustain. Energy Fuels 2021, 5, 5915-5945. [CrossRef]

33. Morales-Guio, C.G.; Stern, L.-A.; Hu, X. Nanostructured hydrotreating catalysts for electrochemical hydrogen evolution. Chem. Soc. Rev. 2014, 43, 6555-6569. [CrossRef]

34. Birss, V.I.; Damjanovic, A.; Hudson, P. Oxygen evolution at platinum electrodes in alkaline solutions: II. Mechanism of the reaction. J. Electrochem. Soc. 1986, 133, 1621. [CrossRef]

35. Conway, B.E.; Liu, T. Characterization of electrocatalysis in the oxygen evolution reaction at platinum by evaluation of behavior of surface intermediate states at the oxide film. Langmuir 1990, 6, 268-276. [CrossRef]

36. Niu, X.; Tang, Q.; He, B.; Yang, P. Robust and stable ruthenium alloy electrocatalysts for hydrogen evolution by seawater splitting. Electrochim. Acta 2016, 208, 180-187. [CrossRef]

37. Millero, F.J.; Feistel, R.; Wright, D.G.; McDougall, T.J. The composition of standard seawater and the definition of the referencecomposition salinity scale. Deep Sea Res. Part I Oceanogr. Res. Pap. 2008, 55, 50-72. [CrossRef]

38. Ayyub, M.M.; Chhetri, M.; Gupta, U.; Roy, A.; Rao, C. Photochemical and photoelectrochemical hydrogen generation by splitting seawater. Chem. Eur. J. 2018, 24, 18455-18462. [CrossRef] [PubMed]

39. Simamora, A.-J.; Hsiung, T.-L.; Chang, F.-C.; Yang, T.-C.; Liao, C.-Y.; Wang, H.P. Photocatalytic splitting of seawater and degradation of methylene blue on $\mathrm{CuO} /$ nano $\mathrm{TiO}_{2}$. Int. J. Hydrogen Energy 2012, 37, 13855-13858. [CrossRef]

40. Jiang, N.; Meng, H.-M.; Song, L.-J.; Yu, H.-Y. Study on Ni-Fe-C cathode for hydrogen evolution from seawater electrolysis. Int. J. Hydrogen Energy 2010, 35, 8056-8062. [CrossRef]

41. Song, L.; Meng, H. Effect of carbon content on Ni-Fe-C electrodes for hydrogen evolution reaction in seawater. Int. J. Hydrogen Energy 2010, 35, 10060-10066. [CrossRef]

42. Li, Y.; Lin, S.; Peng, S.; Lu, G.; Li, S. Modification of $\mathrm{ZnS}_{1-\mathrm{x}-0.5 \mathrm{y}} \mathrm{O}_{\mathrm{x}}(\mathrm{OH})_{\mathrm{y}}-\mathrm{ZnO}$ photocatalyst with NiS for enhanced visible-lightdriven hydrogen generation from seawater. Int. J. Hydrogen Energy 2013, 38, 15976-15984. [CrossRef]

43. Chang, C.-J.; Huang, K.-L.; Chen, J.-K.; Chu, K.-W.; Hsu, M.-H. Improved photocatalytic hydrogen production of ZnO/ZnS based photocatalysts by Ce doping. J. Taiwan Inst. Chem. Eng. 2015, 55, 82-89. [CrossRef]

44. Gao, M.; Connor, P.K.N.; Ho, G.W. Plasmonic photothermic directed broadband sunlight harnessing for seawater catalysis and desalination. Energy Environ. Sci. 2016, 9, 3151-3160. [CrossRef]

45. Yang, T.-C.; Chang, F.-C.; Wang, H.P.; Wei, Y.-L.; Jou, C.-J. Photocatalytic splitting of seawater effected by (Ni-ZnO)@ C nanoreactors. Mar. Pollut. Bull. 2014, 85, 696-699. [CrossRef]

46. Ji, S.M.; Jun, H.; Jang, J.S.; Son, H.C.; Borse, P.H.; Lee, J.S. Photocatalytic hydrogen production from natural seawater. J. Photochem. Photobiol. A Chem. 2007, 189, 141-144. [CrossRef]

47. Wang, M.; Wang, Z.; Gong, X.; Guo, Z. The intensification technologies to water electrolysis for hydrogen production-A review. Renew. Sustain. Energy Rev. 2014, 29, 573-588. [CrossRef]

48. Luo, W.; Yang, Z.; Li, Z.; Zhang, J.; Liu, J.; Zhao, Z.; Wang, Z.; Yan, S.; Yu, T.; Zou, Z. Solar hydrogen generation from seawater with a modified $\mathrm{BiVO}_{4}$ photoanode. Energy Environ. Sci. 2011, 4, 4046-4051. [CrossRef]

49. Dionigi, F.; Reier, T.; Pawolek, Z.; Gliech, M.; Strasser, P. Design criteria, operating conditions, and nickel-iron hydroxide catalyst materials for selective seawater electrolysis. ChemSusChem 2016, 9, 962-972. [CrossRef]

50. Okada, T.; Abe, H.; Murakami, A.; Shimizu, T.; Fujii, K.; Wakabayashi, T.; Nakayama, M. A bilayer structure composed of Mg I $\mathrm{Co}-\mathrm{MnO}_{2}$ deposited on a $\mathrm{Co}(\mathrm{OH})_{2}$ film to realize selective oxygen evolution from chloride-containing water. Langmuir 2020, 36, 5227-5235. [CrossRef]

51. Fujimura, K.; Izumiya, K.; Kawashima, A.; Akiyama, E.; Habazaki, H.; Kumagai, N.; Hashimoto, K. Anodically deposited manganese-molybdenum oxide anodes with high selectivity for evolving oxygen in electrolysis of seawater. J. Appl. Electrochem. 1999, 29, 769-775. [CrossRef]

52. Baniasadi, E.; Dincer, I.; Naterer, G. Electrochemical analysis of seawater electrolysis with molybdenum-oxo catalysts. Int. J. Hydrogen Energy 2013, 38, 2589-2595. [CrossRef]

53. Venkatkarthick, R.; Elamathi, S.; Sangeetha, D.; Balaji, R.; Kannan, B.S.; Vasudevan, S.; Davidson, D.J.; Sozhan, G.; Ravichandran, S. Studies on polymer modified metal oxide anode for oxygen evolution reaction in saline water. J. Electroanal. Chem. 2013, 697, 1-4. [CrossRef]

54. Sohrabnejad-Eskan, I.; Goryachev, A.; Exner, K.S.; Kibler, L.A.; Hensen, E.J.; Hofmann, J.P.; Over, H. Temperature-dependent kinetic studies of the chlorine evolution reaction over $\mathrm{RuO}_{2}$ (110) model electrodes. ACS Catal. 2017, 7, 2403-2411. [CrossRef]

55. Kraft, A.; Stadelmann, M.; Blaschke, M.; Kreysig, D.; Sandt, B.; Schröder, F.; Rennau, J. Electrochemical water disinfection Part I: Hypochlorite production from very dilute chloride solutions. J. Appl. Electrochem. 1999, 29, 859-866. [CrossRef]

56. Vos, J.; Koper, M. Measurement of competition between oxygen evolution and chlorine evolution using rotating ring-disk electrode voltammetry. J. Electroanal. Chem. 2018, 819, 260-268. [CrossRef]

57. Juodkazytė, J.; Šebeka, B.; Savickaja, I.; Petrulevičienė, M.; Butkute, S.; Jasulaitienè, V.; Selskis, A.; Ramanauskas, R. Electrolytic splitting of saline water: Durable nickel oxide anode for selective oxygen evolution. Int. J. Hydrogen Energy 2019, 44, 5929-5939. [CrossRef] 
58. Gayen, P.; Saha, S.; Ramani, V. Selective seawater splitting using pyrochlore electrocatalyst. ACS Appl. Energy Mater. 2020, 3 , 3978-3983. [CrossRef]

59. Tu, Q.; Liu, W.; Jiang, M.; Wang, W.; Kang, Q.; Wang, P.; Zhou, W.; Zhou, F. Preferential adsorption of hydroxide ions onto partially crystalline NiFe-layered double hydroxides leads to efficient and selective OER in alkaline seawater. ACS Appl. Energy Mater. 2021, 4, 4630-4637. [CrossRef]

60. Wu, L.; Yu, L.; Zhang, F.; McElhenny, B.; Luo, D.; Karim, A.; Chen, S.; Ren, Z. Heterogeneous bimetallic phosphide $\mathrm{Ni}_{2} \mathrm{P}-\mathrm{Fe}_{2} \mathrm{P}$ as an efficient bifunctional catalyst for water/seawater splitting. Adv. Funct. Mater. 2021, 31, 2006484. [CrossRef]

61. Wang, S.; Yang, P.; Sun, X.; Xing, H.; Hu, J.; Chen, P.; Cui, Z.; Zhu, W.; Ma, Z. Synthesis of 3D heterostructure Co-doped Fe 2 P electrocatalyst for overall seawater electrolysis. Appl. Catal. B Environ. 2021, 297, 120386. [CrossRef]

62. Zhang, Y.; Fu, C.; Fan, J.; Lv, H.; Hao, W. Preparation of Ti@ NiB electrode via electroless plating toward high-efficient alkaline simulated seawater splitting. J. Electroanal. Chem. 2021, 901, 115761. [CrossRef]

63. Li, J.; Liu, Y.; Chen, H.; Zhang, Z.; Zou, X. Design of a multilayered oxygen-evolution electrode with high catalytic activity and corrosion resistance for saline water splitting. Adv. Funct. Mater. 2021, 2101820. [CrossRef]

64. Cui, B.; Hu, Z.; Liu, C.; Liu, S.; Chen, F.; Hu, S.; Zhang, J.; Zhou, W.; Deng, Y.; Qin, Z. Heterogeneous lamellar-edged $\mathrm{Fe}-\mathrm{Ni}(\mathrm{OH})_{2} / \mathrm{Ni}_{3} \mathrm{~S}_{2}$ nanoarray for efficient and stable seawater oxidation. Nano Res. 2021, 14, 1149-1155. [CrossRef]

65. Wang, S.; Nai, J.; Yang, S.; Guo, L. Synthesis of amorphous Ni-Zn double hydroxide nanocages with excellent electrocatalytic activity toward oxygen evolution reaction. ChemNanoMat 2015, 1, 324-330. [CrossRef]

66. $\mathrm{Hu}, \mathrm{H}$.; Guan, B.; Xia, B.; Lou, X.W. Designed formation of $\mathrm{Co}_{3} \mathrm{O}_{4} / \mathrm{NiCo}_{2} \mathrm{O}_{4}$ double-shelled nanocages with enhanced pseudocapacitive and electrocatalytic properties. J. Am. Chem. Soc. 2015, 137, 5590-5595. [CrossRef]

67. Chi, J.; Yu, H.; Qin, B.; Fu, L.; Jia, J.; Yi, B.; Shao, Z. Vertically aligned FeOOH/NiFe layered double hydroxides electrode for highly efficient oxygen evolution reaction. ACS Appl. Mater. Interfaces 2017, 9, 464-471. [CrossRef]

68. Tang, T.; Jiang, W.-J.; Niu, S.; Liu, N.; Luo, H.; Chen, Y.-Y.; Jin, S.-F.; Gao, F.; Wan, L.-J.; Hu, J.-S. Electronic and morphological dual modulation of cobalt carbonate hydroxides by Mn doping toward highly efficient and stable bifunctional electrocatalysts for overall water splitting. J. Am. Chem. Soc. 2017, 139, 8320-8328. [CrossRef]

69. Izumiya, K.; Akiyama, E.; Habazaki, H.; Kumagai, N.; Kawashima, A.; Hashimoto, K. Anodically deposited manganese oxide and manganese-tungsten oxide electrodes for oxygen evolution from seawater. Electrochim. Acta 1998, 43, 3303-3312. [CrossRef]

70. Fujimura, K.; Matsui, T.; Izumiya, K.; Kumagai, N.; Akiyama, E.; Habazaki, H.; Kawashima, A.; Asami, K.; Hashimoto, K. Oxygen evolution on manganese-molybdenum oxide anodes in seawater electrolysis. Mater. Sci. Eng. A 1999, 267, 254-259. [CrossRef]

71. Ghany, N.A.; Kumagai, N.; Meguro, S.; Asami, K.; Hashimoto, K. Oxygen evolution anodes composed of anodically deposited $\mathrm{Mn}-\mathrm{Mo}-\mathrm{Fe}$ oxides for seawater electrolysis. Electrochim. Acta 2002, 48, 21-28. [CrossRef]

72. Görlin, M.; Ferreira de Araújo, J.; Schmies, H.; Bernsmeier, D.; Dresp, S.R.; Gliech, M.; Jusys, Z.; Chernev, P.; Kraehnert, R.; Dau, H Tracking catalyst redox states and reaction dynamics in Ni-Fe oxyhydroxide oxygen evolution reaction electrocatalysts: The role of catalyst support and electrolyte pH. J. Am. Chem. Soc. 2017, 139, 2070-2082. [CrossRef]

73. Speck, F.D.; Dettelbach, K.E.; Sherbo, R.S.; Salvatore, D.A.; Huang, A.; Berlinguette, C.P. On the electrolytic stability of iron-nickel oxides. Chem 2017, 2, 590-597. [CrossRef]

74. Liu, W.; Jiang, K.; Hu, Y.; Li, Q.; Deng, Y.; Bao, J.; Lei, Y. Zr-doped CoFe-layered double hydroxides for highly efficient seawater electrolysis. J. Colloid Interface Sci. 2021, 604, 767-775. [CrossRef] [PubMed]

75. Wang, Y.; Kong, B.; Zhao, D.; Wang, H.; Selomulya, C. Strategies for developing transition metal phosphides as heterogeneous electrocatalysts for water splitting. Nano Today 2017, 15, 26-55. [CrossRef]

76. Yu, F.; Zhou, H.; Huang, Y.; Sun, J.; Qin, F.; Bao, J.; Goddard, W.A.; Chen, S.; Ren, Z. High-performance bifunctional porous non-noble metal phosphide catalyst for overall water splitting. Nat. Commun. 2018, 9, 1-9. [CrossRef]

77. Chen, J.G. NEXAFS investigations of transition metal oxides, nitrides, carbides, sulfides and other interstitial compounds. Surf. Sci. Rep. 1997, 30, 1-152. [CrossRef]

78. Zhang, Y.; Ouyang, B.; Xu, J.; Chen, S.; Rawat, R.S.; Fan, H.J. 3D porous hierarchical nickel-molybdenum nitrides synthesized by RF plasma as highly active and stable hydrogen-evolution-reaction electrocatalysts. Adv. Energy Mater. 2016, 6, 1600221. [CrossRef]

79. Ham, D.J.; Lee, J.S. Transition metal carbides and nitrides as electrode materials for low temperature fuel cells. Energies 2009, 2, 873-899. [CrossRef]

80. Song, F.; Li, W.; Yang, J.; Han, G.; Liao, P.; Sun, Y. Interfacing nickel nitride and nickel boosts both electrocatalytic hydrogen evolution and oxidation reactions. Nat. Commun. 2018, 9, 1-10. [CrossRef] [PubMed]

81. Wang, Y.; Sun, Y.; Yan, F.; Zhu, C.; Gao, P.; Zhang, X.; Chen, Y. Self-supported NiMo-based nanowire arrays as bifunctional electrocatalysts for full water splitting. J. Mater. Chem. A 2018, 6, 8479-8487. [CrossRef]

82. Zhu, C.; Yin, Z.; Lai, W.; Sun, Y.; Liu, L.; Zhang, X.; Chen, Y.; Chou, S.L. Fe-Ni-Mo nitride porous nanotubes for full water splitting and Zn-air batteries. Adv. Energy Mater. 2018, 8, 1802327. [CrossRef]

83. Gupta, S.; Patel, M.K.; Miotello, A.; Patel, N. Metal boride-based catalysts for electrochemical water-splitting: A review. Adv. Funct. Mater. 2020, 30, 1906481. [CrossRef]

84. Chen, Z.; Duan, X.; Wei, W.; Wang, S.; Zhang, Z.; Ni, B.-J. Boride-based electrocatalysts: Emerging candidates for water splitting. Nano Res. 2020, 13, 293-314. [CrossRef] 
85. Masa, J.; Schuhmann, W. The role of non-metallic and metalloid elements on the electrocatalytic activity of cobalt and nickel catalysts for the oxygen evolution reaction. Chem CatChem 2019, 11, 5842-5854. [CrossRef]

86. Tan, Q.; Zhang, R.; Kong, W.; Qu, F.; Lu, L. Ascorbic acid-loaded apoferritin-assisted carbon dot-MnO 2 nanocomposites for the selective and sensitive detection of trypsin. ACS Appl. Bio Mater. 2018, 1, 777-782. [CrossRef]

87. Xiong, Y.; Dong, J.; Huang, Z.-Q.; Xin, P.; Chen, W.; Wang, Y.; Li, Z.; Jin, Z.; Xing, W.; Zhuang, Z. Single-atom Rh/N-doped carbon electrocatalyst for formic acid oxidation. Nat. Nanotechnol. 2020, 15, 390-397. [CrossRef]

88. Dresp, S.; Thanh, T.N.; Klingenhof, M.; Brückner, S.; Hauke, P.; Strasser, P. Efficient direct seawater electrolysers using selective alkaline NiFe-LDH as OER catalyst in asymmetric electrolyte feeds. Energy Environ. Sci. 2020, 13, 1725-1729. [CrossRef]

89. Lu, X.; Pan, J.; Lovell, E.; Tan, T.H.; Ng, Y.H.; Amal, R. A sea-change: Manganese doped nickel/nickel oxide electrocatalysts for hydrogen generation from seawater. Energy Environ. Sci. 2018, 11, 1898-1910. [CrossRef]

90. Zheng, J. Seawater splitting for high-efficiency hydrogen evolution by alloyed PtNi $\mathrm{x}_{\mathrm{x}}$ electrocatalysts. Appl. Surf. Sci. 2017, 413, 360-365. [CrossRef]

91. Zhang, Y.; Li, P.; Yang, X.; Fa, W.; Ge, S. High-efficiency and stable alloyed nickel based electrodes for hydrogen evolution by seawater splitting. J. Alloys Compd. 2018, 732, 248-256. [CrossRef]

92. Sarno, M.; Ponticorvo, E.; Scarpa, D. Active and stable graphene supporting trimetallic alloy-based electrocatalyst for hydrogen evolution by seawater splitting. Electrochem. Commun. 2020, 111, 106647. [CrossRef]

93. Liu, Y.; Hu, X.; Huang, B.; Xie, Z. Surface engineering of Rh catalysts with N/S-codoped carbon nanosheets toward highPerformance hydrogen evolution from seawater. ACS Sustain. Chem. Eng. 2019, 7, 18835-18843. [CrossRef]

94. Xiu, L.; Pei, W.; Zhou, S.; Wang, Z.; Yang, P.; Zhao, J.; Qiu, J. Multilevel Hollow MXene Tailored Low-Pt Catalyst for Efficient Hydrogen Evolution in Full-pH Range and Seawater. Adv. Funct. Mater. 2020, 30, 1910028. [CrossRef]

95. Miao, J.; Lang, Z.; Zhang, X.; Kong, W.; Peng, O.; Yang, Y.; Wang, S.; Cheng, J.; He, T.; Amini, A. Polyoxometalate-derived hexagonal molybdenum nitrides (MXenes) supported by boron, nitrogen codoped carbon nanotubes for efficient electrochemical hydrogen evolution from seawater. Adv. Funct. Mater. 2019, 29, 1805893. [CrossRef]

96. Lv, Q.; Han, J.; Tan, X.; Wang, W.; Cao, L.; Dong, B. Featherlike NiCoP holey nanoarrys for efficient and stable seawater splitting. ACS Appl. Energy Mater. 2019, 2, 3910-3917. [CrossRef]

97. Tian, F.; Geng, S.; He, L.; Huang, Y.; Fauzi, A.; Yang, W.; Liu, Y.; Yu, Y. Interface engineering: PSS-PPy wrapping amorphous $\mathrm{Ni}$-Co-P for enhancing neutral-pH hydrogen evolution reaction performance. Chem. Eng. J. 2021, 417, 129232. [CrossRef]

98. Wu, D.; Chen, D.; Zhu, J.; Mu, S. Ultralow Ru Incorporated Amorphous Cobalt-Based Oxides for High-Current-Density Overall Water Splitting in Alkaline and Seawater Media. Small 2021, 17, 2102777. [CrossRef] [PubMed]

99. Jin, H.; Wang, X.; Tang, C.; Vasileff, A.; Li, L.; Slattery, A.; Qiao, S.Z. Stable and highly efficient hydrogen evolution from seawater enabled by an unsaturated nickel surface nitride. Adv. Mater. 2021, 33, 2007508. [CrossRef]

100. Yu, L.; Wu, L.; Song, S.; McElhenny, B.; Zhang, F.; Chen, S.; Ren, Z. Hydrogen Generation from Seawater Electrolysis over a Sandwich-like NiCoN I Ni $\mathrm{P}$ I NiCoN Microsheet Array Catalyst. ACS Energy Lett. 2020, 5, 2681-2689. [CrossRef]

101. Huang, Y.; Hu, L.; Liu, R.; Hu, Y.; Xiong, T.; Qiu, W.; Balogun, M.-S.J.T.; Pan, A.; Tong, Y. Nitrogen treatment generates tunable nanohybridization of $\mathrm{Ni}_{5} \mathrm{P}_{4}$ nanosheets with nickel hydr (oxy) oxides for efficient hydrogen production in alkaline, seawater and acidic media. Appl. Catal. B Environ. 2019, 251, 181-194. [CrossRef]

102. Grigoriev, S.; Millet, P.; Fateev, V. Evaluation of carbon-supported Pt and Pd nanoparticles for the hydrogen evolution reaction in PEM water electrolysers. J. Power Sources 2008, 177, 281-285. [CrossRef]

103. Renjith, A.; Roy, A.; Lakshminarayanan, V. In situ fabrication of electrochemically grown mesoporous metallic thin films by anodic dissolution in deep eutectic solvents. J. Colloid Interface Sci. 2014, 426, 270-279. [CrossRef]

104. Fang, Y.-H.; Liu, Z.-P. Mechanism and tafel lines of electro-oxidation of water to oxygen on $\mathrm{RuO}_{2}$ (110). J. Am. Chem. Soc. 2010, 132, 18214-18222. [CrossRef] [PubMed]

105. Trasatti, S. Progress in the understanding of the mechanism of chlorine evolution at oxide electrodes. Electrochim. Acta 1987, 32, 369-382. [CrossRef]

106. Trasatti, S. Work function, electronegativity, and electrochemical behaviour of metals: III. Electrolytic hydrogen evolution in acid solutions. J. Electroanal. Chem. Interfacial Electrochem. 1972, 39, 163-184. [CrossRef]

107. Conway, B.; Jerkiewicz, G. Nature of electrosorbed $\mathrm{H}$ and its relation to metal dependence of catalysis in cathodic $\mathrm{H}_{2}$ evolution. Solid State Ion. 2002, 150, 93-103. [CrossRef]

108. Conway, B.; Jerkiewicz, G. Relation of energies and coverages of underpotential and overpotential deposited $\mathrm{H}$ at Pt and other metals to the 'volcano curve'for cathodic $\mathrm{H}_{2}$ evolution kinetics. Electrochim. Acta 2000, 45, 4075-4083. [CrossRef]

109. Yang, S.-C.; Pang, S.H.; Sulmonetti, T.P.; Su, W.-N.; Lee, J.-F.; Hwang, B.-J.; Jones, C.W. Synergy between ceria oxygen vacancies and $\mathrm{Cu}$ nanoparticles facilitates the catalytic conversion of $\mathrm{CO}_{2}$ to $\mathrm{CO}$ under mild conditions. ACS Catal. 2018, 8, 12056-12066. [CrossRef]

110. Sarno, M.; Sannino, D.; Leone, C.; Ciambelli, P. Evaluating the effects of operating conditions on the quantity, quality and catalyzed growth mechanisms of CNTs. J. Mol. Catal. A Chem. 2012, 357, 26-38. [CrossRef]

111. Lukatskaya, M.R.; Mashtalir, O.; Ren, C.E.; Dall'Agnese, Y.; Rozier, P.; Taberna, P.L.; Naguib, M.; Simon, P.; Barsoum, M.W.; Gogotsi, Y. Cation intercalation and high volumetric capacitance of two-dimensional titanium carbide. Science 2013, 341, 1502-1505. [CrossRef] 
112. Liu, J.; Zhang, H.B.; Sun, R.; Liu, Y.; Liu, Z.; Zhou, A.; Yu, Z.Z. Hydrophobic, flexible, and lightweight MXene foams for high-performance electromagnetic-interference shielding. Adv. Mater. 2017, 29, 1702367. [CrossRef]

113. Ma, T.Y.; Cao, J.L.; Jaroniec, M.; Qiao, S.Z. Interacting carbon nitride and titanium carbide nanosheets for high-performance oxygen evolution. Angew. Chem. 2016, 128, 1150-1154. [CrossRef]

114. Pang, S.-Y.; Wong, Y.-T.; Yuan, S.; Liu, Y.; Tsang, M.-K.; Yang, Z.; Huang, H.; Wong, W.-T.; Hao, J. Universal strategy for HF-free facile and rapid synthesis of two-dimensional MXenes as multifunctional energy materials. J. Am. Chem. Soc. 2019, 141, 9610-9616. [CrossRef]

115. Ma, Y.-Y.; Wu, C.-X.; Feng, X.-J.; Tan, H.-Q.; Yan, L.-K.; Liu, Y.; Kang, Z.-H.; Wang, E.-B.; Li, Y.-G. Highly efficient hydrogen evolution from seawater by a low-cost and stable CoMoP@ C electrocatalyst superior to Pt/C. Energy Environ. Sci. 2017, 10, 788-798. [CrossRef]

116. Lovell, E.C.; Lu, X.; Zhang, Q.; Scott, J.; Amal, R. From passivation to activation-tunable nickel/nickel oxide for hydrogen evolution electrocatalysis. Chem. Commun. 2020, 56, 1709-1712. [CrossRef] [PubMed]

117. Anantharaj, S.; Noda, S. Amorphous catalysts and electrochemical water splitting: An untold story of harmony. Small 2020, 16, 1905779. [CrossRef]

118. Jiang, K.; Liu, W.; Lai, W.; Wang, M.; Li, Q.; Wang, Z.; Yuan, J.; Deng, Y.; Bao, J.; Ji, H. NiFe layered double hydroxide/FeOOH heterostructure nanosheets as an efficient and durable bifunctional electrocatalyst for overall seawater splitting. Inorg. Chem. 2021, 60, 17371-17378. [CrossRef]

119. Pi, Y.; Shao, Q.; Wang, P.; Lv, F.; Guo, S.; Guo, J.; Huang, X. Trimetallic oxyhydroxide coralloids for efficient oxygen evolution electrocatalysis. Angew. Chem. Int. Ed. 2017, 56, 4502-4506. [CrossRef]

120. Xu, H.; Wang, B.; Shan, C.; Xi, P.; Liu, W.; Tang, Y. Ce-doped NiFe-layered double hydroxide ultrathin nanosheets/nanocarbon hierarchical nanocomposite as an efficient oxygen evolution catalyst. ACS Appl. Mater. Interfaces 2018, 10, 6336-6345. [CrossRef]

121. Huang, L.; Chen, D.; Luo, G.; Lu, Y.R.; Chen, C.; Zou, Y.; Dong, C.L.; Li, Y.; Wang, S. Zirconium-regulation-induced bifunctionality in 3D cobalt-iron oxide nanosheets for overall water splitting. Adv. Mater. 2019, 31, 1901439. [CrossRef] [PubMed]

122. Liu, B.; He, B.; Peng, H.Q.; Zhao, Y.; Cheng, J.; Xia, J.; Shen, J.; Ng, T.W.; Meng, X.; Lee, C.S. Unconventional nickel nitride enriched with nitrogen vacancies as a high-efficiency electrocatalyst for hydrogen evolution. Adv. Sci. 2018, 5, 1800406. [CrossRef]

123. Jin, H.; Gu, Q.; Chen, B.; Tang, C.; Zheng, Y.; Zhang, H.; Jaroniec, M.; Qiao, S.-Z. Molten salt-directed catalytic synthesis of 2D layered transition-metal nitrides for efficient hydrogen evolution. Chem 2020, 6, 2382-2394. [CrossRef]

124. Niu, S.; Fang, Y.; Zhou, J.; Cai, J.; Zang, Y.; Wu, Y.; Ye, J.; Xie, Y.; Liu, Y.; Zheng, X. Manipulating the water dissociation kinetics of $\mathrm{Ni}_{3} \mathrm{~N}$ nanosheets via in situ interfacial engineering. J. Mater. Chem. A 2019, 7, 10924-10929. [CrossRef]

125. Liu, Y.; Zhang, J.; Li, Y.; Qian, Q.; Li, Z.; Zhu, Y.; Zhang, G. Manipulating dehydrogenation kinetics through dual-doping $\mathrm{Co}_{3} \mathrm{~N}$ electrode enables highly efficient hydrazine oxidation assisting self-powered $\mathrm{H}_{2}$ production. Nat. Commun. 2020, 11, 1-13. [CrossRef]

126. Wang, T.; Wang, M.; Yang, H.; Xu, M.; Zuo, C.; Feng, K.; Xie, M.; Deng, J.; Zhong, J.; Zhou, W. Weakening hydrogen adsorption on nickel via interstitial nitrogen doping promotes bifunctional hydrogen electrocatalysis in alkaline solution. Energy Environ. Sci. 2019, 12, 3522-3529. [CrossRef]

127. Salamat, A.; Hector, A.L.; Kroll, P.; McMillan, P.F. Nitrogen-rich transition metal nitrides. Coord. Chem. Rev. 2013, 257, 2063-2072. [CrossRef]

128. You, B.; Liu, X.; Hu, G.; Gul, S.; Yano, J.; Jiang, D.-E.; Sun, Y. Universal surface engineering of transition metals for superior electrocatalytic hydrogen evolution in neutral water. J. Am. Chem. Soc. 2017, 139, 12283-12290. [CrossRef]

129. Wang, S.; Yu, X.; Lin, Z.; Zhang, R.; He, D.; Qin, J.; Zhu, J.; Han, J.; Wang, L.; Mao, H.-K. Synthesis, crystal structure, and elastic properties of novel tungsten nitrides. Chem. Mater. 2012, 24, 3023-3028. [CrossRef]

130. Imbihl, R.; Behm, R.J.; Ertl, G.; Moritz, W. The structure of atomic nitrogen adsorbed on Fe (100). Surf. Sci. 1982, 123, 129-140. [CrossRef] 